\title{
Facies architecture of the Early Devonian Ural Volcanics, New South Wales
}

\author{
K. F. BULL* AND J. MCPHIE
}

Centre for Ore Deposit Research (CODES-SRC) and School of Earth Sciences, University of Tasmania, Private

Bag 79, Hobart, Tas. 7001, Australia.

\begin{abstract}
The Ural Volcanics are a early Devonian, submarine, felsic lava-sill complex, exposed in the western central Lachlan Orogen, New South Wales. The Ural Volcanics and underlying Upper Silurian, deepwater, basin-fill sedimentary rocks make up the Rast Group. The Ural Range study area, centrally located in the Cargelligo 1:100000 map sheet area, was mapped at 1:10000 scale. Seventeen principal volcanic facies were identified in the study area, dominated by felsic coherent facies (rhyolite and dacite) and associated monomictic breccia and siltstone-matrix monomictic breccia facies. Subordinate volcaniclastic facies include the pumice-rich breccia facies association, rhyolite-dacitesiltstone breccia facies and fiamme-siltstone breccia facies. The sedimentary facies association includes mixed-provenance and non-volcanic sandstone to conglomerate, black mudstone, micaceous quartz sandstone and foliated mudstone. The succession was derived from at least two intrabasinal volcanic centres. One, in the north, was largely effusive and intrusive, building a lava-sill complex. Another, in the south, was effusive, intrusive and explosive, generating lavas and moderatevolume $\left(\sim 3 \mathrm{~km}^{3}\right)$ pyroclastic facies. The presence of turbidites, marine fossils, very thick massive to graded volcaniclastic units and black mudstone, and the lack of large-scale cross-beds and erosional scours, provide evidence for deposition in a submarine environment below storm wave-base. The Ural Volcanics have potential for seafloor or sub-seafloor replacement massive sulfide deposits, although no massive sulfide prospects or related altered zones have yet been defined. Sparse, disseminated sulfides occur in sericite-altered, steeply dipping shear zones.
\end{abstract}

KEY WORDS: Devonian, facies architecture, felsic volcanic rocks, Lachlan Orogen, pyroclastics, submarine volcanism, Ural Volcanics.

\section{INTRODUCTION}

The western central Lachlan Orogen in New South Wales includes predominantly felsic volcanic successions associated with several parallel, north-southelongated sedimentary basins formed in the Late Silurian to Middle Devonian (Cas 1983; Trigg 1987; Scheibner 1998; Colquhoun et al. 2005). Ore deposits and prospects occur in these sedimentary and volcanic rocks in the Cobar, Mt Hope and Lake Cargelligo areas, although their origins have not been resolved (O'Connor \& Sangster 1980; Robertson \& Taylor 1987; Stegman 2001). The basins have been mapped at 1:250000 and 1:100 000 scales (Pogson 1967; Scheibner \& Barron 1985; Trigg 1987; Colquhoun et al. 2005), but little detailed work has been carried out on the character and setting of the associated volcanic successions.

The Ural Volcanics were first named by Griffin (1960) as part of the (then) Cargelligo Group and are located on the Cargelligo 1:100 000 map sheet area (Colquhoun et al. 2005) in central New South Wales (Figure 1). In this paper, new data are reported based on detailed mapping of the Ural Volcanics, specifically in the Ural Range area. The Ural Volcanics in the Ural Range are predominantly felsic and also silicified, rendering them quite resistant to erosion. The result is exceptional exposure of a submarine volcanic succession that has allowed detailed mapping of facies geometry and textures. Textural preservation is also excellent, and far better than in other exposures of the Ural Volcanics elsewhere. The facies and facies associations making up the Ural Volcanics are described and used to define the facies architecture of the succession. The prospectivity of the area is also briefly discussed. The terminology used to describe volcanic facies is that of McPhie et al. (1993). Location grid references are quoted in Map Grid of Australia (MGA) zone 55, in metres.

\section{REGIONAL SETTING AND AGE OF THE URAL VOLCANICS}

The Ural Volcanics are exposed from the southern Kilparney 1:100 000 map sheet area (Trigg 1987), southward across the Cargelligo and Rankin Springs 1:100 000 map sheet areas (Figure 1a) (Colquhoun et al. 2005). The

*Corresponding author and current address: Alaska Volcano Observatory, Alaska Division Geological \& Geophysical Surveys, 3354 College Road, Fairbanks, AK 99709, USA (kate_bull@dnr.state.ak.us). 


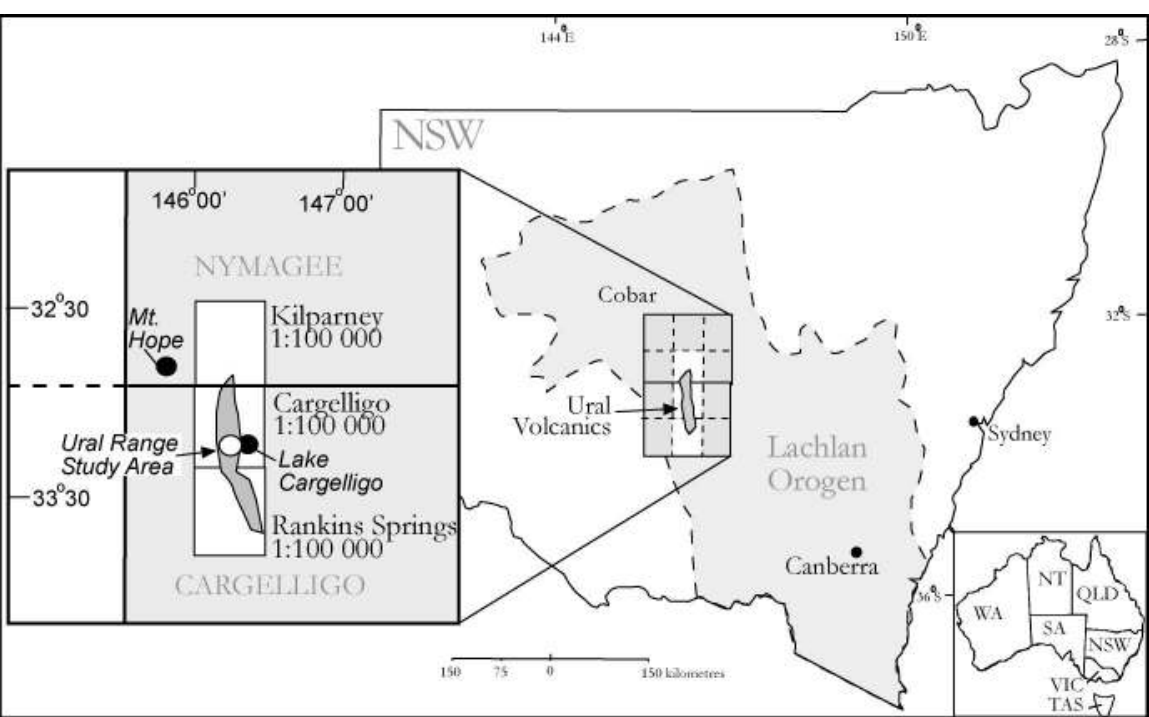

a.

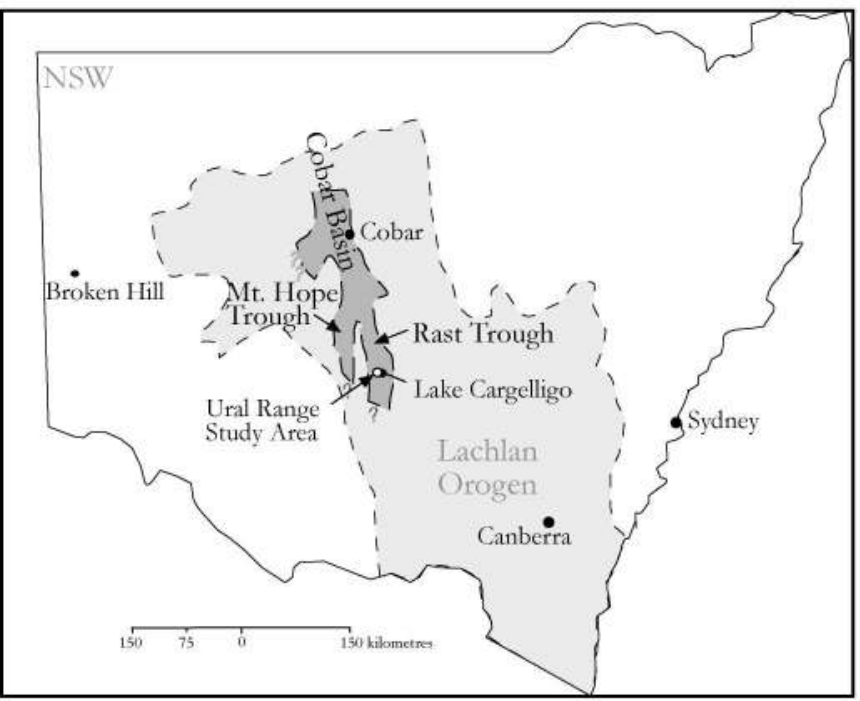

b.

oldest rocks in the Cargelligo area are the poorly exposed and strongly deformed Wagga Group (in part formerly the Tallebung Group: Figure 2), an Ordovician sequence of submarine sedimentary rocks (Pogson 1967; Colquhoun et al. 2005). The Boothumble Formation unconformably overlies the Ordovician Wagga Group. The formation consists of quartz-rich sandstone interpreted to be a basement-derived, subaerial alluvial-fan facies and has been assigned to the Pridoli (Trigg 1987; Colquhoun et al. 2005). The Rast Group conformably overlies the Boothumble Formation in the Kilparney 1:100 000 map sheet area (Trigg 1987), but contacts with underlying and overlying groups are not exposed in the Cargelligo 1:100 000 map sheet area. The Rast Group, in the Cargelligo 1:100 000 map sheet area, comprises the Crossleys Tank Formation, the Preston Formation and the Ural Volcanics (Figure 2). The Gurragong Volcanics, the Melougel Ignimbrite and the Nyora Granite are also included in the Rast Group, but they are not exposed in the Cargelligo 1:100 000 map sheet area.

The Ural Volcanics conformably overlie a basin-fill sequence of quartz-rich turbidites (Crossleys Tank
Figure 1 (a) Location of the Ural Volcanics in the Lachlan Orogen, New South Wales, and of the Ural Range study area in relation to the 1:250000 (Nymagee and Cargelligo) and 1:100000 (Kilparney, Cargelligo and Rankin Springs) map sheet areas. (b) Location of the Cobar Basin and the Mt Hope and Rast Troughs (dark grey) in the Lachlan Orogen (after Suppel \& Scheibner 1990).
Formation) or, locally, volcaniclastic and fossiliferous sandstone (Preston Formation) (Figure 2). The Preston Formation conformably overlies the Crossleys Tank Formation east of the Ural Range, and occurs in drillcore at the Browns Reef $\mathrm{Pb}, \mathrm{Zn}$ ( $\mathrm{Ag}, \mathrm{Cu}, \mathrm{Au})$ deposit (Maniw 1983; Colquhoun et al. 2005). The shallow-marine sedimentary Walters Range Group has been mapped as age-equivalent to, and possibly overlying, the upper Ural Volcanics to the north on the Kilparney 1:100000 map sheet (Trigg 1987), but no stratigraphic relationships are exposed in the Cargelligo area.

The age of the Ural Volcanics is constrained by a combination of fossils and SHRIMP $\mathrm{U}-\mathrm{Pb}$ zircon dates. Marine fossils found at the southern end of the Ural Range (425824E 6301921N) give a probable Pragian to Emsian age (middle Early Devonian: Meakin et al. 2002; Colquhoun et al. 2005). Zircons from rhyolite at four locations in the Cargelligo 1:100000 map sheet area provided ages of $410 \pm 8,414 \pm 13,413 \pm 5$ and $424 \pm 6 \mathrm{Ma}$ (latest Silurian to Early Devonian: Figure 2). The oldest age was considered to be a result of inheritance (Meakin et al. 2002). 


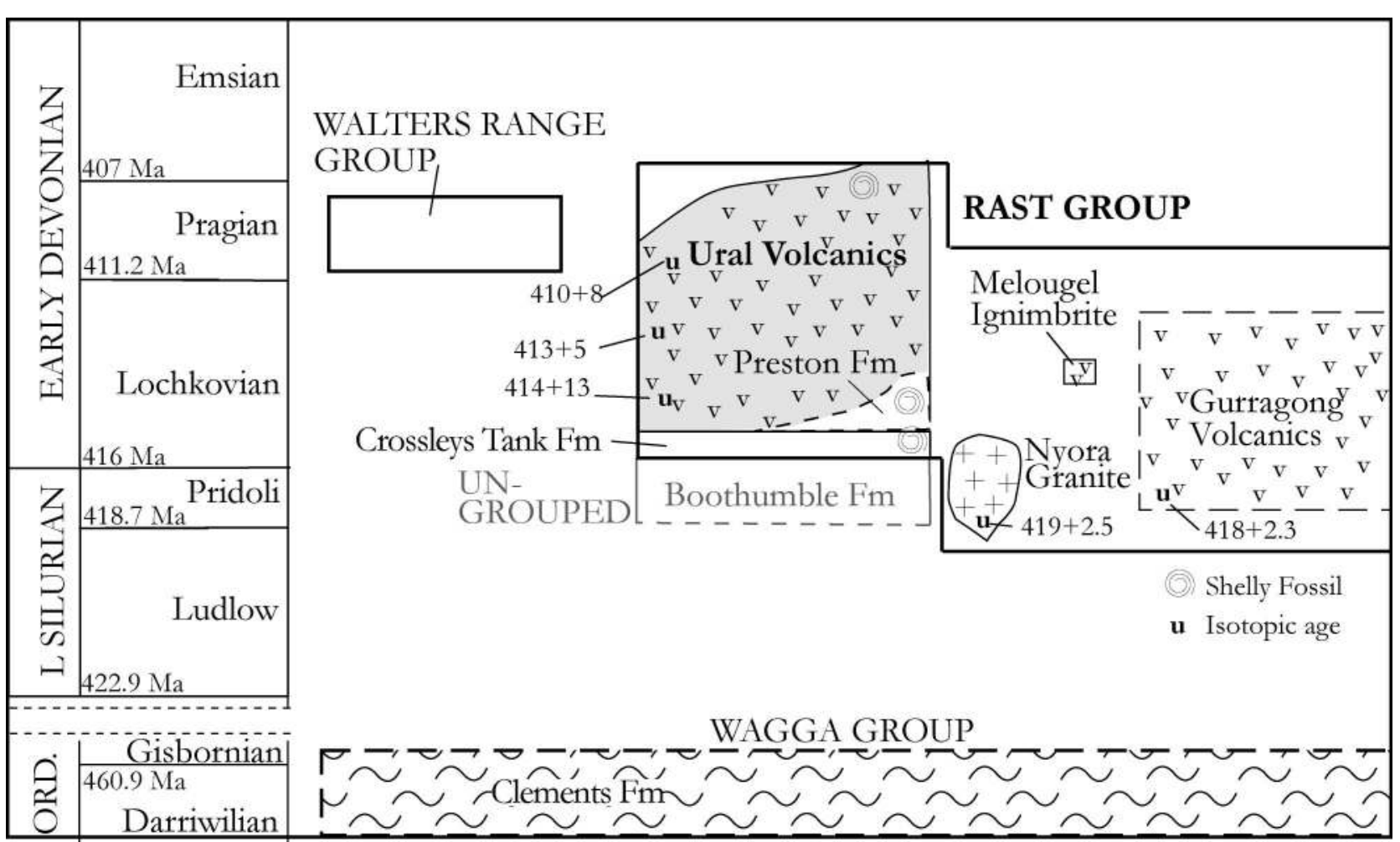

Figure 2 Stratigraphic relationships among the Wagga Group, Walters Range Group and Rast Group. The Rast Group includes the Crossleys Tank Formation, the Preston Formation, the Ural Volcanics, the Melougel Ignimbrite, the Gurragong Volcanics and the Nyora Granite (Colquhoun et al. 2005). The underlying Boothumble Formation is not exposed in the Cargelligo 1:250 000 map sheet area but has a gradational, conformable contact with the Rast Group in the Kilparney 1:100 000 map sheet area (Trigg 1987). Ages are constrained by fossils and U-Pb SHRIMP dates on zircons (Colquhoun et al. 2005). Modified after Colquhoun et al. (2005); time-scale from Gradstein and Ogg (2004).

The Ural Volcanics and the underlying sedimentary rocks lie within the Rast Trough, a north-southelongated basin which is parallel to, and south of, the Cobar Basin and Mt Hope Trough (Figure 1b) (Scheibner 1998). The basins are believed to have formed in response to Early to Middle Silurian northeast-southwest extension (Glen et al. 1996). Both the Mt Hope and the Rast Troughs contain significant volumes of volcanic rocks (Scheibner \& Barron 1985; Colquhoun et al. 2005). During the Middle Devonian to Early Carboniferous, the area was affected by at least one regional deformation event involving northeast-southwest shortening that caused the basins to close and, in some areas, to invert (Glen et al. 1996). Movement along related northeast-striking shear zones has resulted in at least one, and locally two, slaty to spaced cleavages in phyllosilicate-rich lithologies. These events were accompanied by middle to upper greenschist-grade regional metamorphism.

The Ural Volcanics are characterised by high $\mathrm{SiO}_{2}$ (most samples $>68 \mathrm{wt} \%$, and up to $77 \mathrm{wt} \%$ ), Ba (755 ppm), Zr (358 ppm), Nb (25 ppm), REE (rare-earth elements) $(\mathrm{Ce}=137), \mathrm{Y}(66 \mathrm{ppm})$ and $\mathrm{Ga}(21 \mathrm{ppm})$, and low $\mathrm{Mg} \#\left[\mathrm{Mg} /\left(\mathrm{Mg}+\mathrm{Fe}^{\text {total }}\right)\right]$ (Blevin 2004; Colquhoun et al. 2005). Zircon saturation temperatures were also reported to be very high, with upper values in the range $900-910^{\circ} \mathrm{C}$ for samples with $\mathrm{SiO}_{2}=70-74 \mathrm{wt} \%$ (Blevin 2003; Colquhoun et al. 2005). The presence of elevated high field strength elements, low Mg\# and high $\mathrm{Ga} / \mathrm{Al}$ $(\geq 2.5)$, in addition to high zircon saturation tempera- tures, suggest that the Ural Volcanics have aluminous A-type compositions, as defined by King et al. (1997) (Blevin 2003; Colquhoun et al. 2005; Bull 2006).

\section{GEOLOGY OF THE URAL RANGE MAP AREA}

This study is based on 1:10000 scale mapping of the Ural Range, $12 \mathrm{~km}$ west of Lake Cargelligo and $\sim 200 \mathrm{~km}$ south of Cobar (Figure 1). In the Ural Range, the Ural Volcanics are $\sim 1000 \mathrm{~m}$ thick and cover $\sim 80 \mathrm{~km}^{2}$. The succession youngs and dips moderately southwards, and in general, only very weak cleavage is present. Original textures are very well preserved in most of the area, the exception being local intensely quartz-albite- and chlorite-sericite-altered domains. Any originally glassy domains or clasts are now composed of fine-grained quartz-K-feldspar-phyllosilicate aggregates. Greenschist-grade metamorphism has altered plagioclase phenocrysts to albite and ferromagnesian minerals to assemblages of chlorite \pm sericite, titanite and ilmenite, and uncommon epidote.

\section{Structure of the Ural Range}

Bedding measurements from the Ural Volcanics in the Ural Range are limited to stratified facies and rare coherent/clastic facies contacts. Beds typically dip between $10^{\circ}$ and $40^{\circ}$ towards the south (Figure 3 ). 


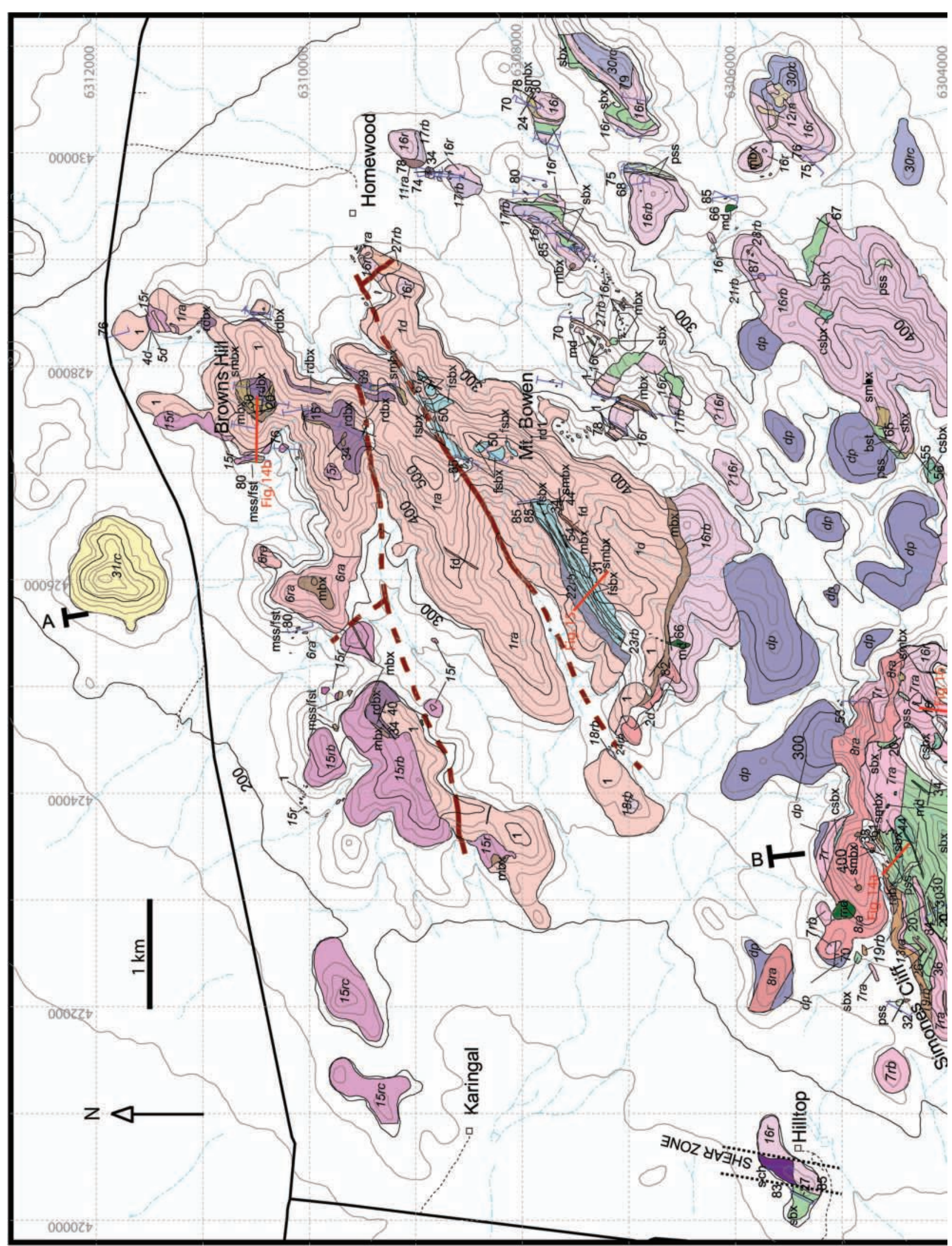

ர் 


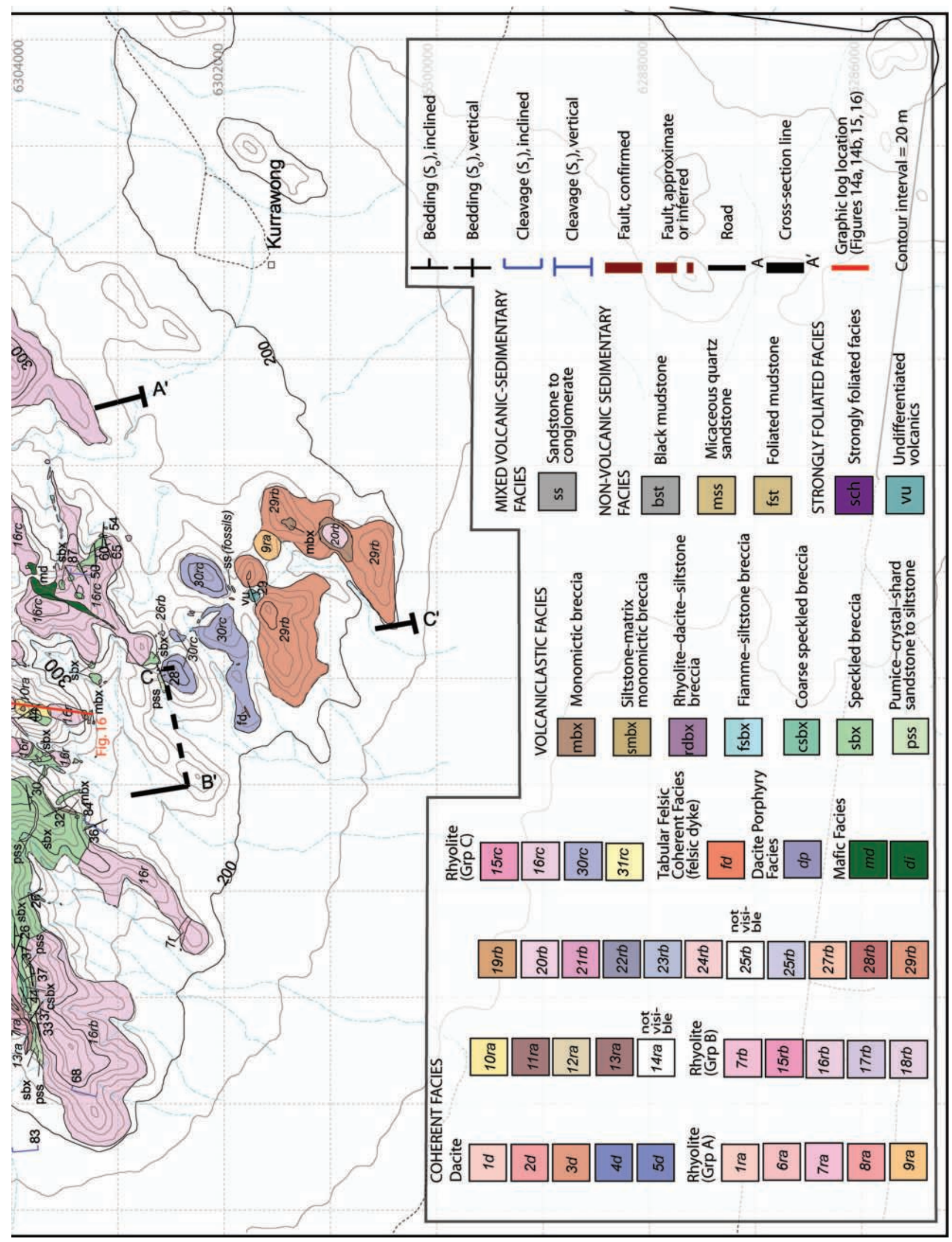



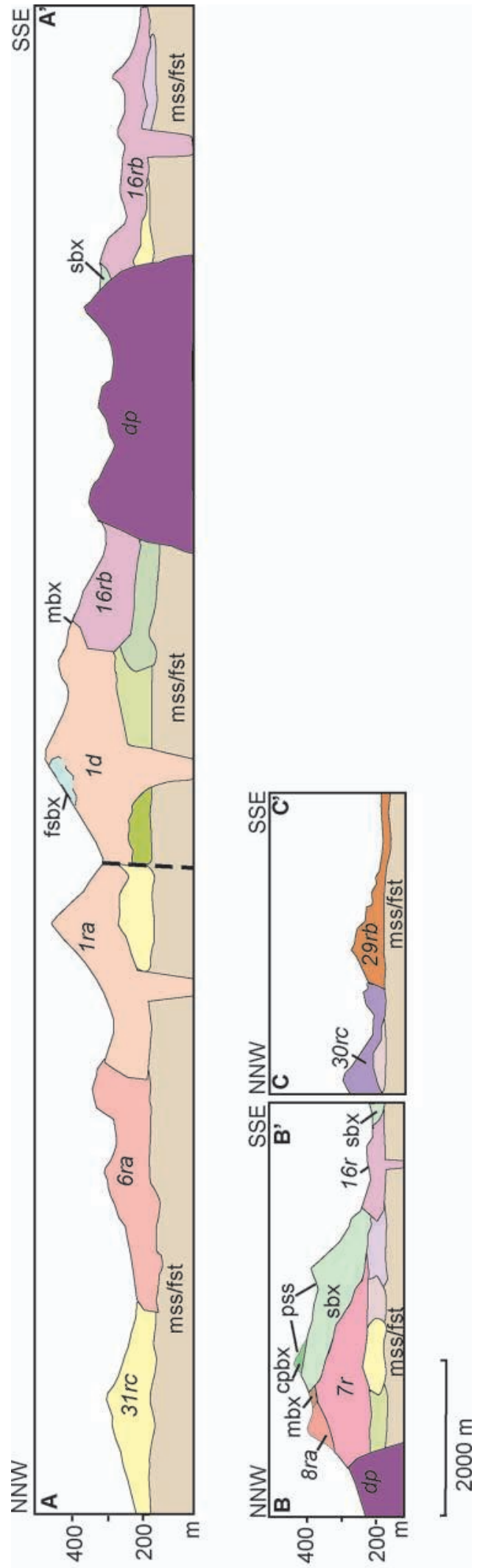

蓠劳营

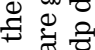

$\exists$ ब

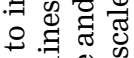

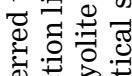

过

वें ठैं

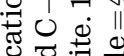

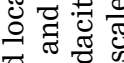

素

舟出

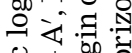

记娄

क्षे की है

पै

o क के

要

क्ष

is

艺

है है

政

बैं⿰彳
Locally, beds may dip as steeply as $75^{\circ}$. In the northern to southeastern part of the map area, beds dip to the southeast. In the southwestern part of the map area, they dip to the southwest. Mapped units rarely have exposed contacts, but their outcrop patterns imply that contacts are gently dipping to flat-lying. The structure so defined is an open, southwest-plunging fold, and younging directions indicate that the fold is an anticline. The fold axis, determined from the distribution of poles to bedding, plunges $29^{\circ}$ towards $207^{\circ}$ (Figure 4). No synclinal axis was identified on either side of the anticline, so the fold wavelength is greater than the width of the Ural Range ( $>10 \mathrm{~km}$ ).

Overall, the strain in the Ural Volcanics is interpreted to be very low. A penetrative to centimetre-scale spaced cleavage, $\mathrm{S}_{1}$, is visible in the least-silicified facies. The cleavage consistently dips $75^{\circ}$ to $90^{\circ}$ towards the southeast or northwest. In thin-sections from oriented samples, the $S_{1}$ cleavage is visible in some facies. In pumice-rich clastic facies, the $S_{1}$ cleavage occurs as anastomosing, narrow concentrations of chlorite and sericite, and has folded and crenulated a compaction fabric defined by flattened pumice fragments. In the coherent facies, $S_{1}$ is very weak and may be defined by dissolution textures such as stylolites (Figure 5) or rare quartz, chlorite or sericite strain fringes adjacent to equant quartz crystals.

The majority of $S_{1}$ measurements $(\sim 80 \%$ : Figure $4 \mathrm{~b})$ are close to, but not axial planar to, the fold identified using the bedding data (Figure $4 \mathrm{a}, \mathrm{c}$ ). The $\mathrm{S}_{1}$ cleavage is locally folded into small-amplitude ( $10-30 \mathrm{~mm})$, close to open, gently south-plunging, asymmetric minor folds, which have produced some of the scatter in the poles to the $S_{1}$ surfaces. Some of the variation in $S_{1}$ is due to cleavage refraction associated with lithological differences (i.e. more phyllosilicate-rich facies versus more siliceous facies). However, the slight transection of the regional fold (Figure 4c) could be the result of a second folding event.

Two northeast- to east-northeast-striking, steeply dipping faults have been mapped in the northern half of the map area (Figure 3). Rubble composed of sericiteand clay-rich rocks, locally also containing minor pyrrhotite, and white quartz \pm carbonate veins is common in saddles cut by the faults, and cleavage is locally more intense. Northwest-striking faults intersect the northeast to east-northeast faults, but their relationship to those faults is unclear. On the western side of the Ural Range (420467E 6305597N), a 300 m-wide zone of strongly foliated rhyolite and quartz-feldspar-sericite schist is exposed. The zone strikes $\sim 010^{\circ}$, but it was not seen along-strike on the hills $\sim 3.5 \mathrm{~km}$ to the northnortheast.

\section{Mineralisation}

Sulfides identified in the Ural Volcanics include pyrite, pyrrhotite, chalcopyrite, galena and sphalerite. Sulfides are associated with sericite-altered domains and can be disseminated or occur as stringers or small lenses concentrated in steeply dipping fault zones, but generally amount to less than 5 modal $\%$. White quartz \pm carbonate veins have been prospected historically in the 
Figure 4 Equal-area stereographic projections for the Ural Volcanics in the Ural Range (using GEOrient ment of Earth Sciences, University of Queensland). (a) Poles to bedding $\left(\mathrm{S}_{0} ; n=71\right)$, defining an upright, open anticline, with a fold axis $(\beta)$ that plunges $30^{\circ}$ to $202^{\circ}$. (b) Poles to cleavage $\left(\mathrm{S}_{1}\right.$; $n=57$ ), contoured with respect to point density. Although there is appreciable scatter in the $\mathrm{S}_{1}$ data, the mean $\mathrm{S}_{1}$ dips $89^{\circ}$ towards $281^{\circ}$. (c) The mean $S_{1}$ plotted on (a), does not contain the fold axis $(\beta)$. Hence, the fold appears to be slightly transected $\left(\sim 11^{\circ}\right.$; double arrow) by the regional cleavage. software; (c) R. Holcombe, Depart-

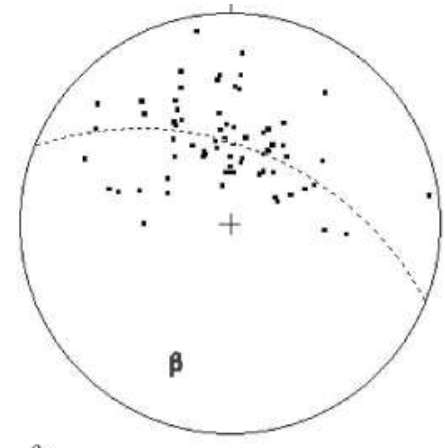

a.
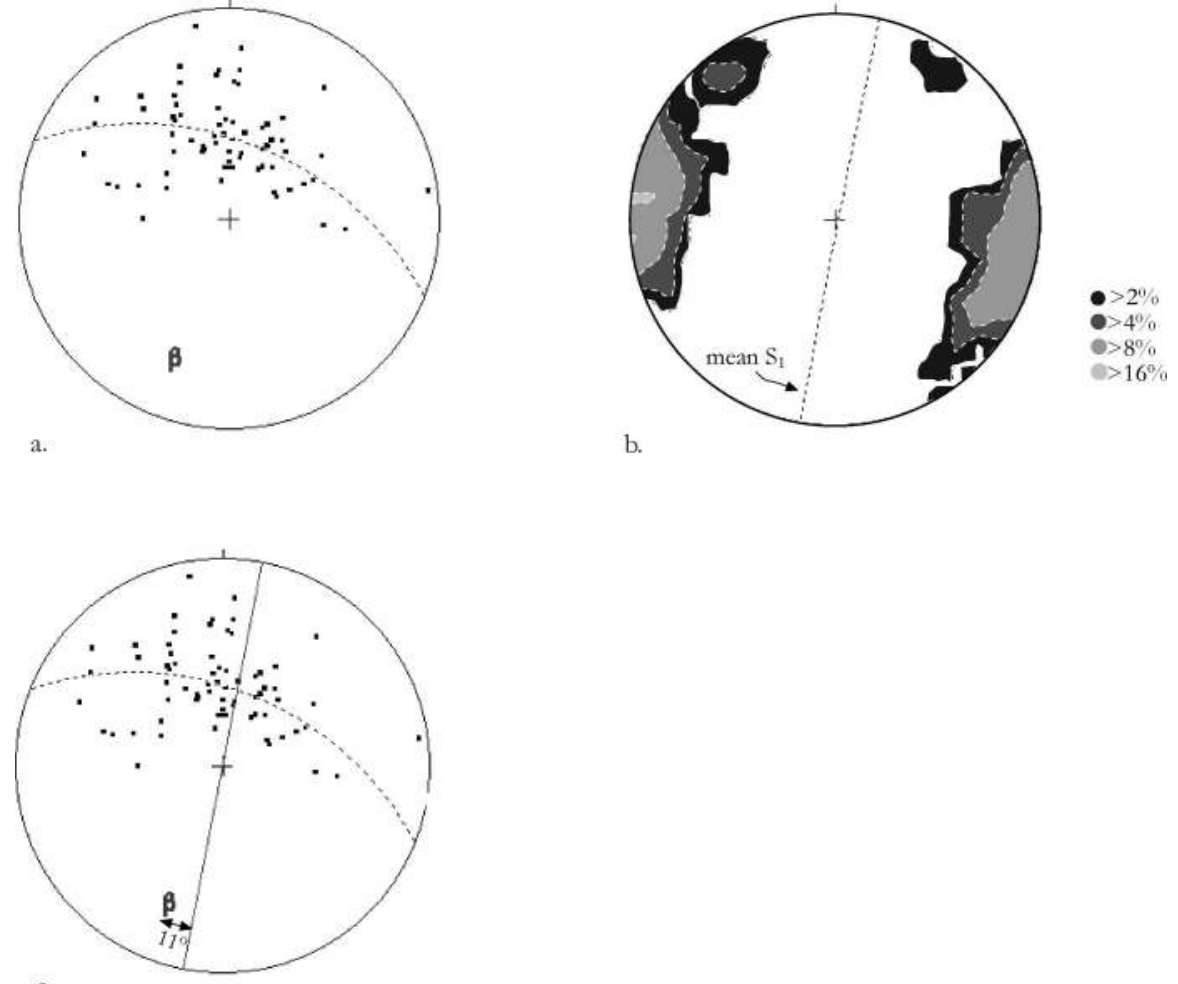

c.

associated with carbonate-, chlorite- and silica-altered rocks.

In the eastern part of the Ural Range, a quarry (435737E 6303817N) has exposed pervasively clay- (and sericite?)-altered, highly foliated, quartz-phyric schist. The schist is cut by steep southwest- and southeastdipping veins and by stockwork veins that consist of quartz and iron oxides. No sulfides were seen in the quarry area during this study. The altered schist and veins extend at least $500 \mathrm{~m}$ to the northwest from the quarry.

\section{FACIES OF THE URAL VOLCANICS}

The Ural Volcanics are dominated by a variety of felsic coherent facies, with less-voluminous, texturally diverse felsic volcaniclastic facies (Table 1). In addition, there are subordinate mafic coherent facies, mixed volcanic-sedimentary facies and non-volcanic sedimentary facies.

\section{Coherent Facies}

area, but only one shaft was sunk by prospectors in the northeastern Ural Range (Ural Mine, 426803E 6310144N: Downes 2005), and minor gold and base metals were reported. Minor galena and sphalerite associated with $5-10 \%$ pyrite were intersected in drillcore on the western side of the Ural Range (Kemptons Grid, 420363E 6305834N: Downes 2005), but no significant metal concentrations were reported. Base metals have been found in the underlying Preston Formation, and mined at Browns Reef, east of the Ural Range (Maniw 1980, 1983; Paull 1987). Browns Reef was reported to be

\section{FELSIC COHERENT FACIES}

The felsic coherent facies are characterised by porphyritic or equigranular crystalline textures. At least 35 separate units composed of felsic coherent facies (Table 2) were mapped on the basis of phenocryst mineralogy, size, abundance and relative proportions. However, geochemical analyses (Bull 2006) indicate that in a few instances, the modal mineralogy is not a good indicator of composition; for example, some strongly quartz-phyric samples are dacites, and some quartz-free 


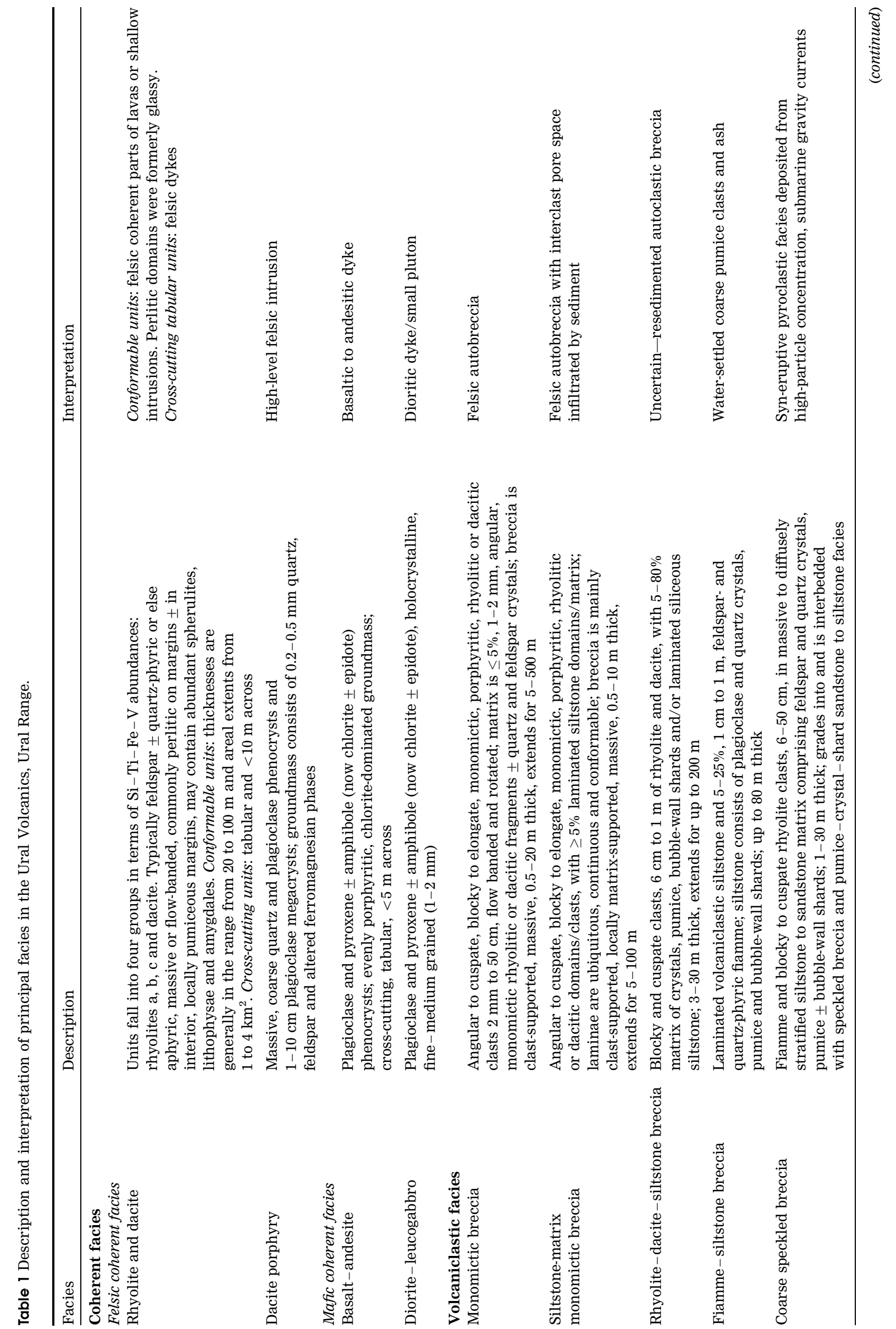




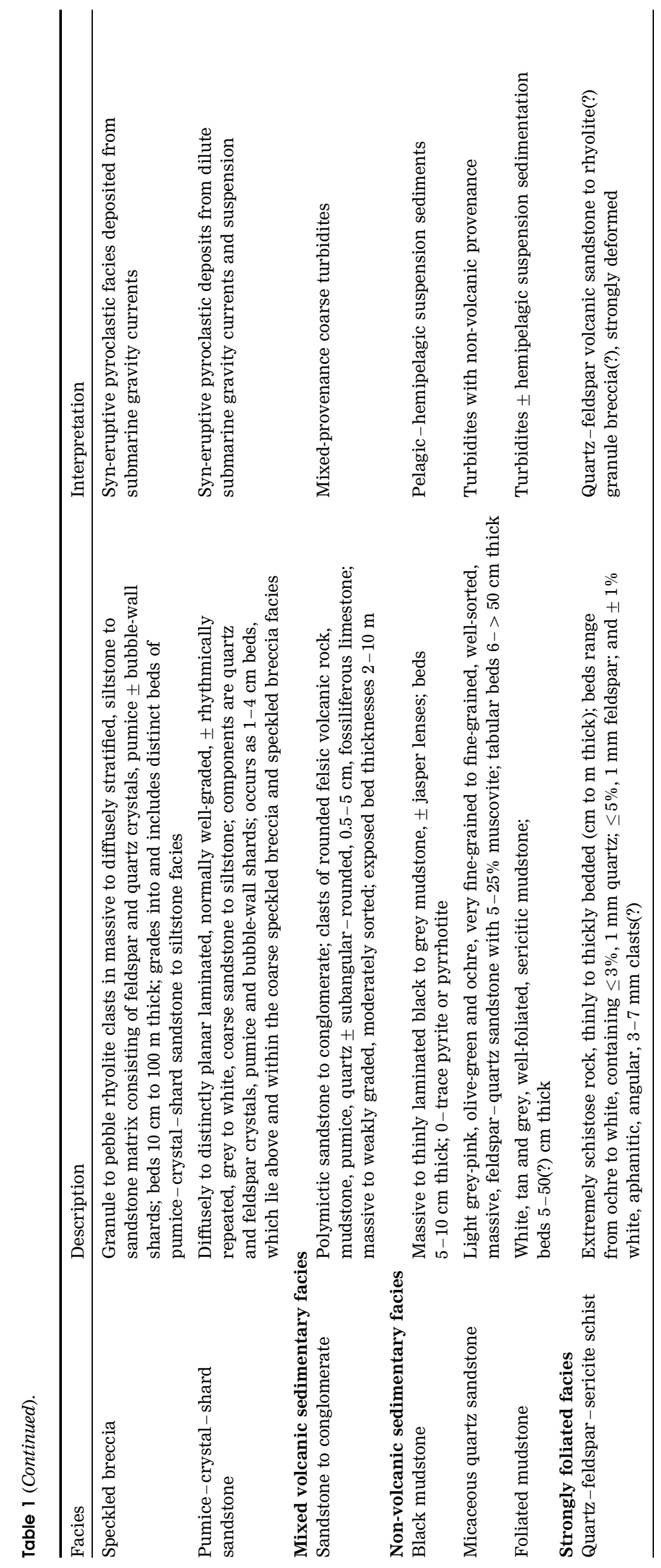




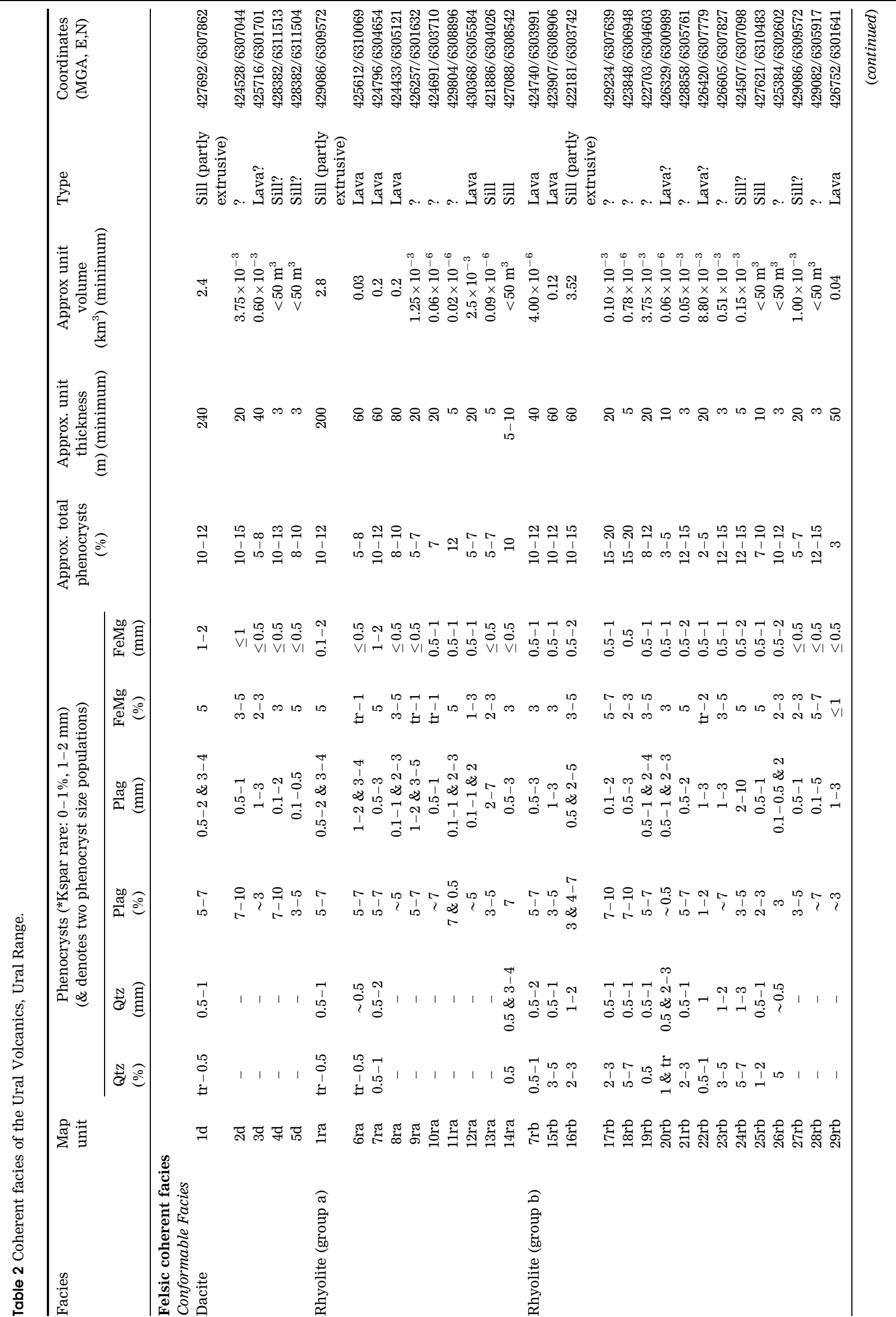


samples are rhyolites. As a result, the felsic coherent units have been named based on their $\mathrm{SiO}_{2}$ abundances: Ural Volcanics rhyolites contain $69.9-77 \mathrm{wt} \% \mathrm{SiO}_{2}$, and dacites contain $66.7-67.8 \mathrm{wt} \% \quad \mathrm{SiO}_{2}$. The analyses also indicate that the rhyolites fall into three groups in terms of $\mathrm{Si}-\mathrm{Ti}-\mathrm{Fe}-\mathrm{V}$ contents (Table 2): group a (69.9-73 wt $\% \mathrm{SiO}_{2}, 0.36-0.66 \mathrm{wt} \% \mathrm{TiO}_{2}$ ), group b (72.6$75.6 \mathrm{wt} \% \mathrm{SiO}_{2}, 0.19-0.36 \mathrm{wt} \% \mathrm{TiO}_{2}$ ) and group c (76.7$77.2 \mathrm{wt} \% \mathrm{SiO}_{2}, 0.18-0.25 \mathrm{wt} \% \mathrm{TiO}_{2}$ ). In addition, some texturally uniform mappable units can be subdivided on the basis of composition, particularly $\mathrm{Si}-\mathrm{Fe}-\mathrm{Ti}-\mathrm{V}$ contents. These units include: 1 (dacite and rhyolite a); $15 \mathrm{r}$ (rhyolites b and c); 16r (rhyolites b and c); and $7 \mathrm{r}$ (rhyolites a and b) (Figure 3; Table 2) (Bull 2006). For units that were not analysed, no composition label has been assigned on the map.

The modal phenocryst abundances in the felsic coherent facies are rarely $>10 \%$, and can be as low as 1\% (Table 2; Figure 6). The predominant phenocryst phase is plagioclase. Sieve-textured plagioclase crystals occur in some units and are characteristic of unit 1 . Quartz phenocryst abundance is variable (typically 0 $7 \%$ ), and K-feldspar is mostly restricted to the groundmass. Ferromagnesian phenocrysts generally amount to $<5 \%$ and are altered to chlorite \pm biotite \pm actinolite \pm titanite \pm epidote \pm illite/smectite \pm leucoxene. Their shapes suggest they were probably amphibole or less commonly biotite and/or pyroxene. Glomeroporphyritic aggregates of plagioclase, altered ferromagnesian minerals and opaque phases are common, especially in unit 1. Common accessory minerals include ilmenite, zircon, apatite and fluorite, although the fluorite typically occurs with small, irregular quartz veinlets and therefore may be secondary. Secondary disseminated pyrite, pyrrhotite and rare chalcopyrite occur in trace amounts up to $\sim 2 \%$ in some units.

The groundmass in the felsic coherent facies consists of intergrown, generally anhedral K-feldspar \pm plagioclase \pm quartz. Chlorite ( \pm sericite, biotite, epidote)altered ferromagnesian minerals are also rarely present. Grainsizes vary from $\leq 0.01 \mathrm{~mm}$ to $0.05 \mathrm{~mm}$, and the groundmass may contain amygdales, spherulites or lithophysae (Figure 7). Amygdales range from sub-millimetre to $>20 \mathrm{~cm}$ in length and are infilled by intergrown anhedral quartz and/or chlorite \pm biotite \pm carbonate. Spherulites and lithophysae range from sub-millimetre to $\sim 5 \mathrm{~cm}$ in diameter, may be aligned along flow bands, and may be isolated or in clusters.

Most felsic coherent units in the study area were in part formerly glassy, as they locally exhibit perlitic texture close to contacts. Some units, for example unit $1 d$, exhibit columnar joints. Many are locally pumiceous close to contacts. These textures were not used to delineate map units or facies, because more than one texture is typically present within a single coherent map unit. However, the groundmass textures do help to distinguish coherent from volcaniclastic facies. Patchy domains of secondary quartz-albite and chloritesericite assemblages have locally obscured the primary textures in felsic coherent facies units and have produced pseudoclastic textures (Figure 7d).

Most felsic coherent units have thicknesses of $20-$ $100 \mathrm{~m}$, areal extents of $1-4 \mathrm{~km}^{2}$, and maximum lateral 


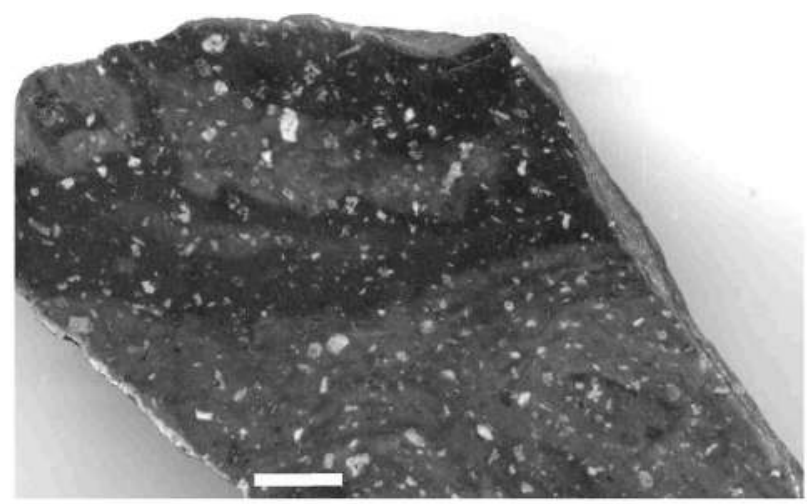

a

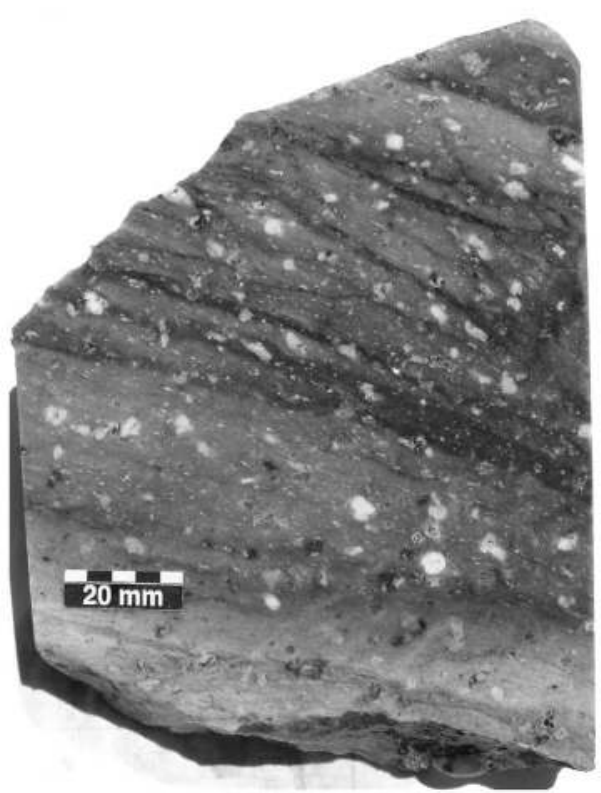

b.
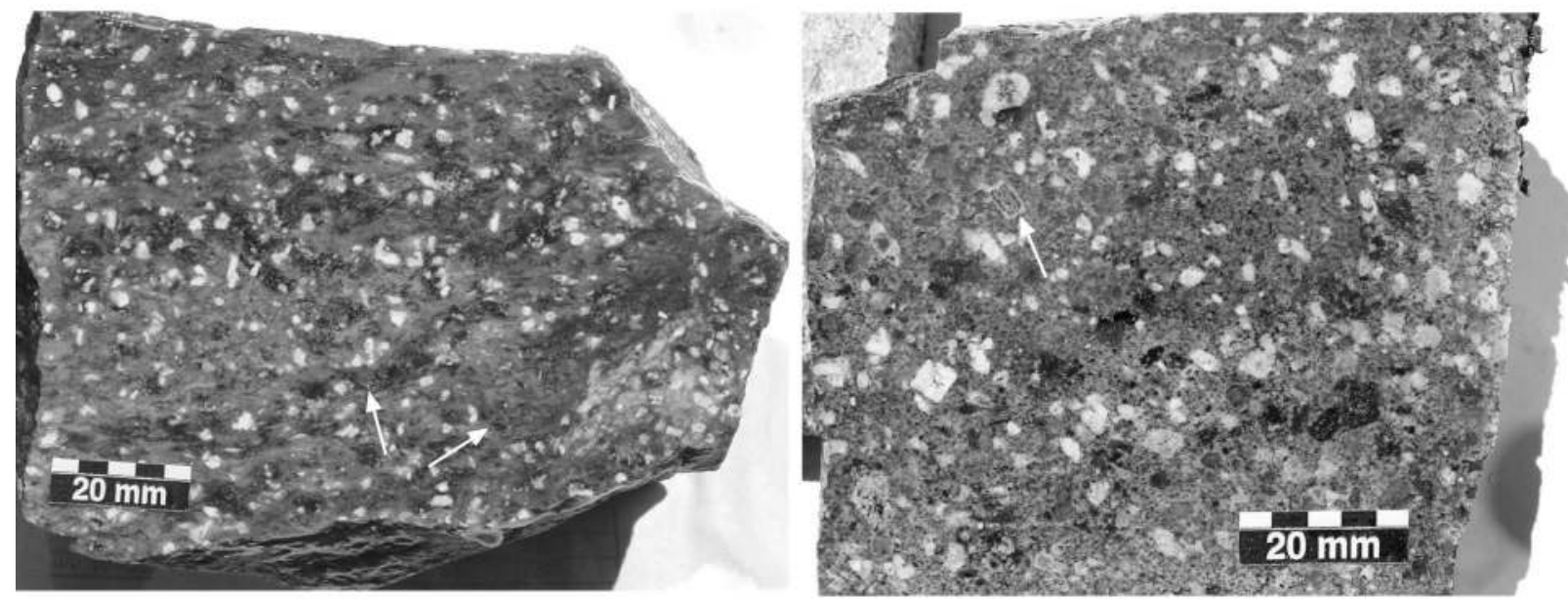

c.

d.

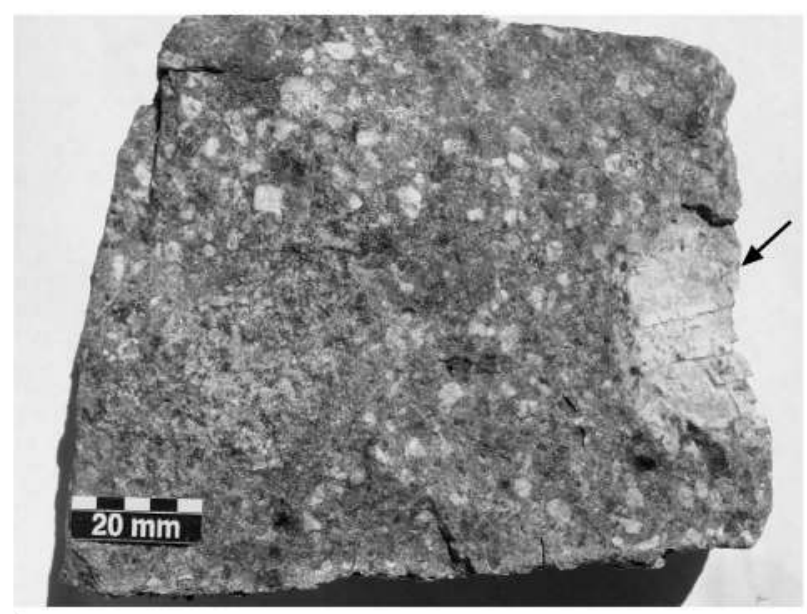

e.

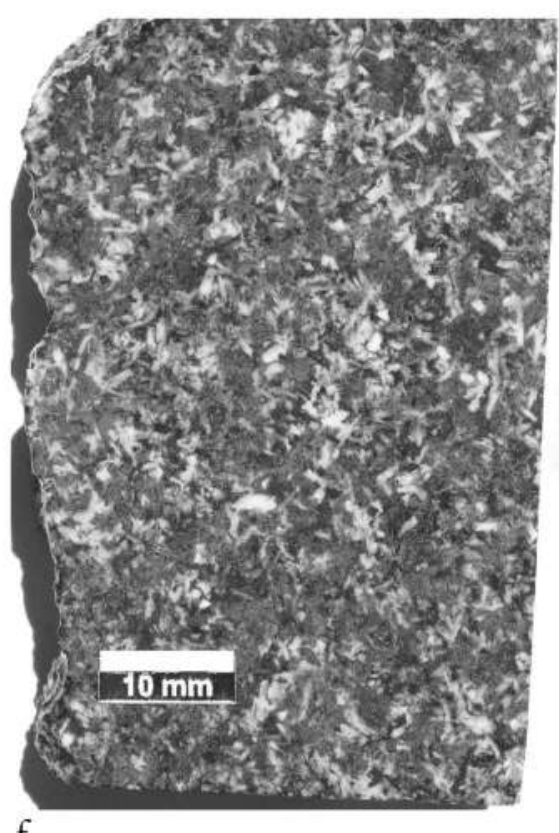

f. 
extents of $2 \mathrm{~km}$ (Figure 3; Table 2). Exceptions include unit 1d (Figure 3), which is at least $1.5 \times 5 \mathrm{~km}$ in area and over $220 \mathrm{~m}$ thick, unit 1ra (Figures $3,6 \mathrm{e}$ ), which is $\sim 7 \times 2 \mathrm{~km}$ in area and $\geq 200 \mathrm{~m}$ thick, and unit $16 \mathrm{rb}$ (Figures 3, 6a), which is exposed over an area $12 \times 3 \mathrm{~km}$ and is at least $150 \mathrm{~m}$ thick.

The dacite porphyry facies (unit dp: Table 2; Figure $6 \mathrm{~b}, \mathrm{c}$ ) occurs as a circular to elliptical body in the centre of the Ural Range map area (Figure 3). Contacts are sharp with all units, including two separate rhyolite units (16r and 1ra), black mudstone, and the pumice-rich facies association.

\section{MAFIC COHERENT FACIES}

The mafic coherent facies are characterised by evenly porphyritic or equigranular crystalline textures and include the basalt-andesite facies and the
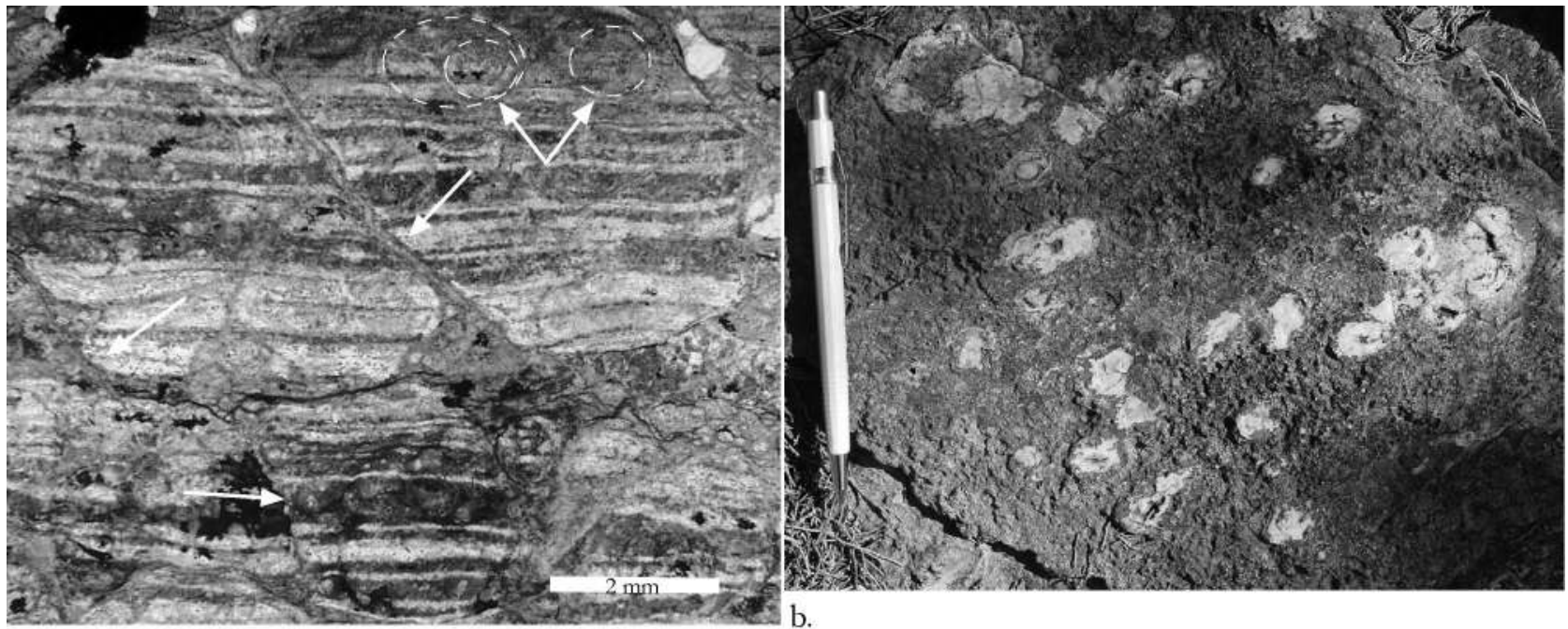

a.

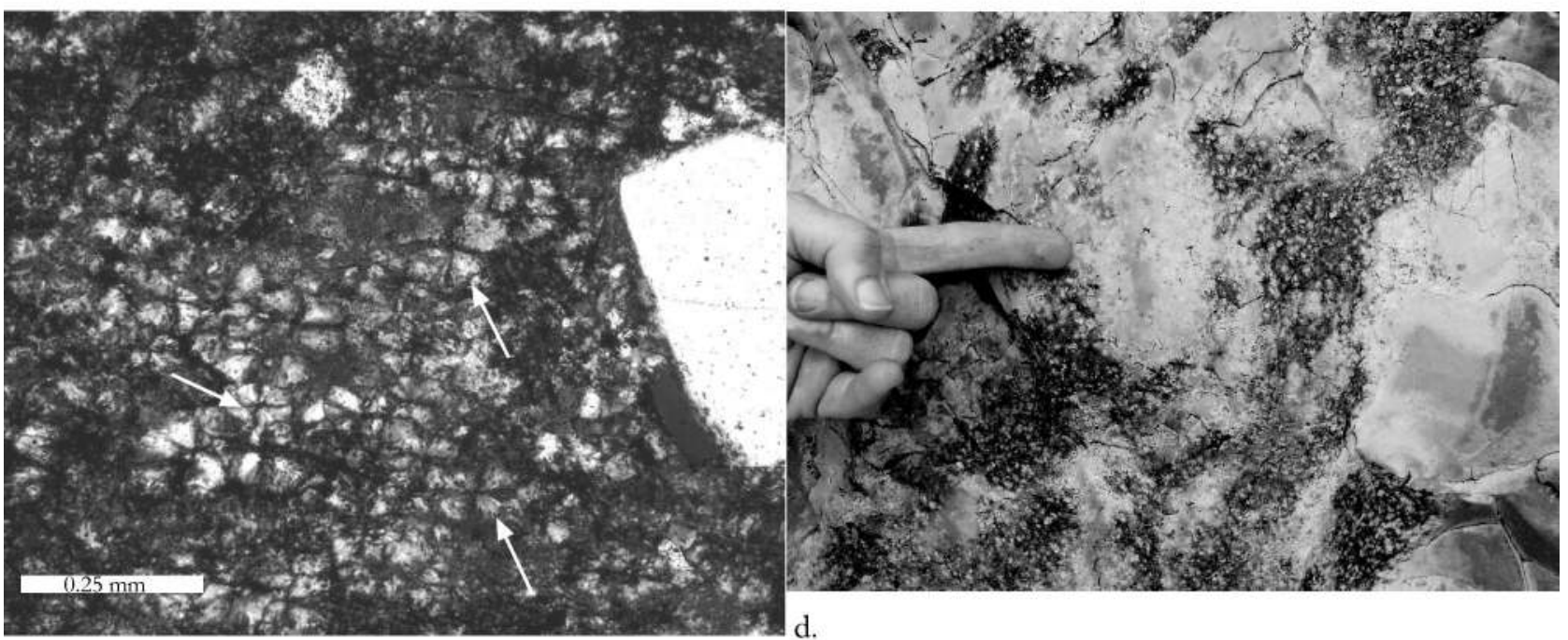

c.

Figure 7 Textures in felsic coherent facies. (a) Perlitic fractures (arrows) in flow-banded 16rb rhyolite (427182E 6303313N). (b) Lithophysae (white, circular shapes) in 19rb rhyolite (422232E 6304178N). (c) Photomicrograph of microspherulitic texture in the groundmass of $16 \mathrm{rb}$ rhyolite $(422181 \mathrm{E} 6303743 \mathrm{~N})$. Small crosses (arrows) are radiating, fibrous quartz and feldspar microspherulites; the phenocryst on right side is plagioclase. Cross-polarised light. (d) Patchy chlorite \pm sericite (dark) and quartz -albite (pale) domains in $1 \mathrm{~d}$ dacite $(426223 \mathrm{E} 6307850 \mathrm{~N})$ give an apparent fragmental texture; the uniform phenocryst distribution and phenocrysts crossing 'clast' margins suggest instead that the facies is coherent.

Figure 6 Felsic and mafic coherent facies. (a) Rhyolite (group a) facies (8ra: 424459E 6305057N). Dark bands are secondary chlorite along flow bands. (b) Rhyolite (group b) facies (16rb: 428969E 630950N). Dark bands are secondary chlorite along flow bands. (c) Dacite facies (1d: 428967E 6309507N). Patchy dark domains are secondary chlorite along flow bands. (d, e) Dacite porphyry facies (dp; 428308E 6305666N): (d) polished rock slab, note sieve-textured plagioclase (arrow) with chloritic core; (e) uncut sample, note plagioclase megacryst (arrow). (f) Mafic coherent facies (diorite-leucogabbro: 422943E 6305267N). Amphibole and pyroxene are partially altered to chlorite and epidote, and plagioclase feldspar crystals are acicular. 
diorite-leucogabbro facies (Tables 1,2 ). The basaltandesite facies is more common than the dioriteleucogabbro facies and is typically found in units with tabular morphology that cut felsic coherent facies and volcaniclastic facies. The diorite-leucogabbro facies (Figures 3, 6f) occurs as dykes or small circular intrusions ( $\leq 50 \mathrm{~m}$ in diameter). All mafic coherent facies exhibit very weak to moderate cleavage.

\section{Volcaniclastic facies}

There are seven volcaniclastic facies (Table 1): monomictic breccia; siltstone-matrix monomictic breccia; rhyolite-dacite-siltstone breccia; fiamme-siltstone breccia; and three, closely related pumice-rich breccia facies. Each volcaniclastic facies is represented by a single map unit (Figure 3).

\section{MONOMICTIC BRECCIA}

The monomictic breccia facies (Table 1) is clast-supported and contains $<5 \%$ matrix. The clasts are angular, cuspate to blocky rhyolite or dacite. A minor proportion of the clasts are wispy. The clasts are commonly flowbanded, and millimetres to tens of centimetres in length (Figure 8). The matrix is made up of millimetre-sized angular fragments of the same composition as the larger clasts. The monomictic breccia facies occurs on the margin of, and within, coherent units of the same composition.

\section{SILTSTONE-MATRIX MONOMICTIC BRECCIA}

The siltstone-matrix monomictic breccia facies contains lenses or domains ( $>5 \%$ ) of continuously and delicately laminated, white to grey siltstone, centimetres to a metre in length between blocky to cuspate, commonly flow-banded and monomictic porphyritic clasts that show jigsaw-fit texture (Figure 9). The laminae are ubiquitous and continuous throughout the lenses and in abrupt contact with the clasts. The siltstone commonly consists of a fine-grained $(<0.1 \mathrm{~mm})$ mosaic of quartz and feldspar, and laminae are defined by very finegrained $(\leq 0.1 \mathrm{~mm})$ sericite and/or chlorite.

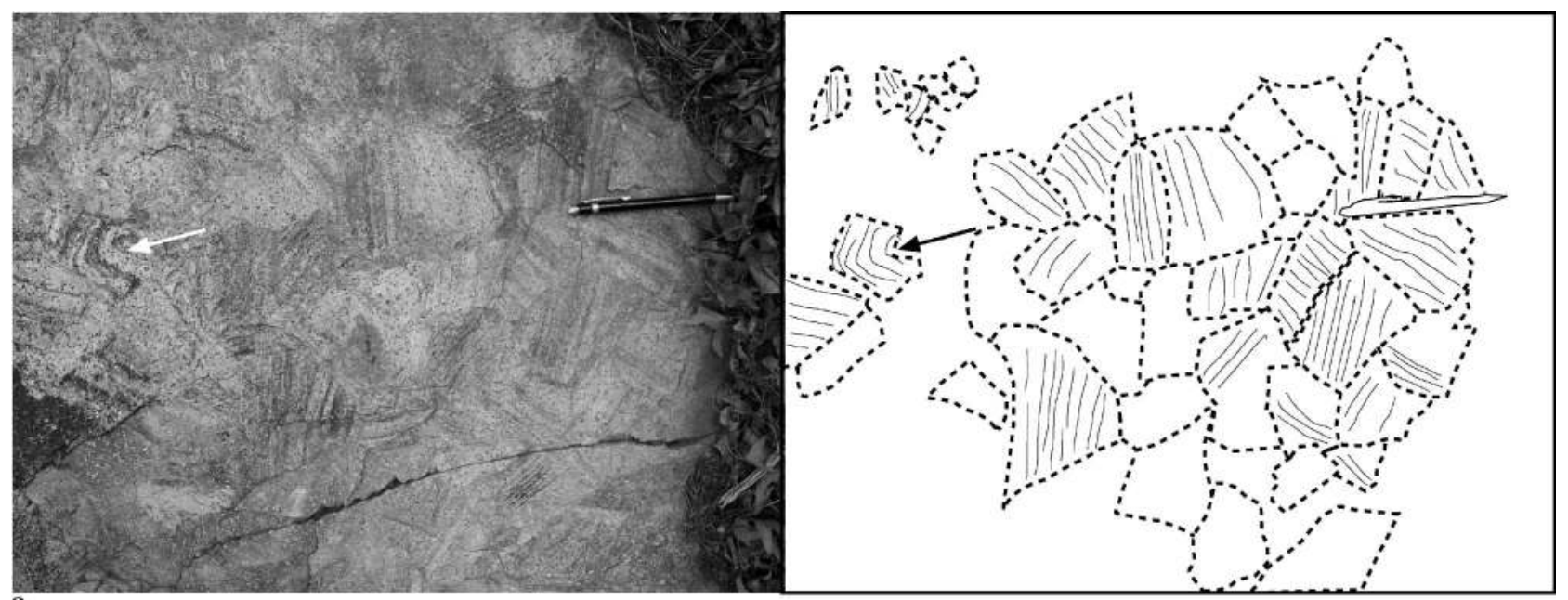

a.

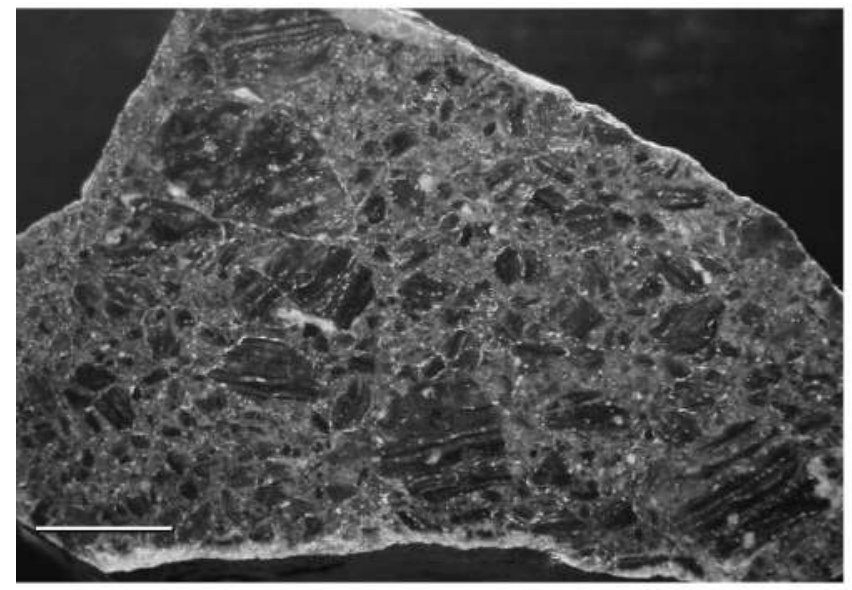

b.

Figure 8 Monomictic breccia facies. (a) Outcrop shows closely packed, rotated, flow-banded clasts of 7ra rhyolite (422936E $6304312 \mathrm{~N}$ ). Note folded flow bands in one clast (arrow). Line drawing on the right highlights clast outlines and flow bands. Pencil is $13 \mathrm{~cm}$ long. (b) Monomictic breccia with blocky, rotated, flow-banded clasts of 16rc rhyolite (425104E 6303267N). Matrix consists of small $(\leq 2 \mathrm{~mm})$ angular $16 \mathrm{rc}$ rhyolite clasts. Scale bar, $1 \mathrm{~cm}$. 


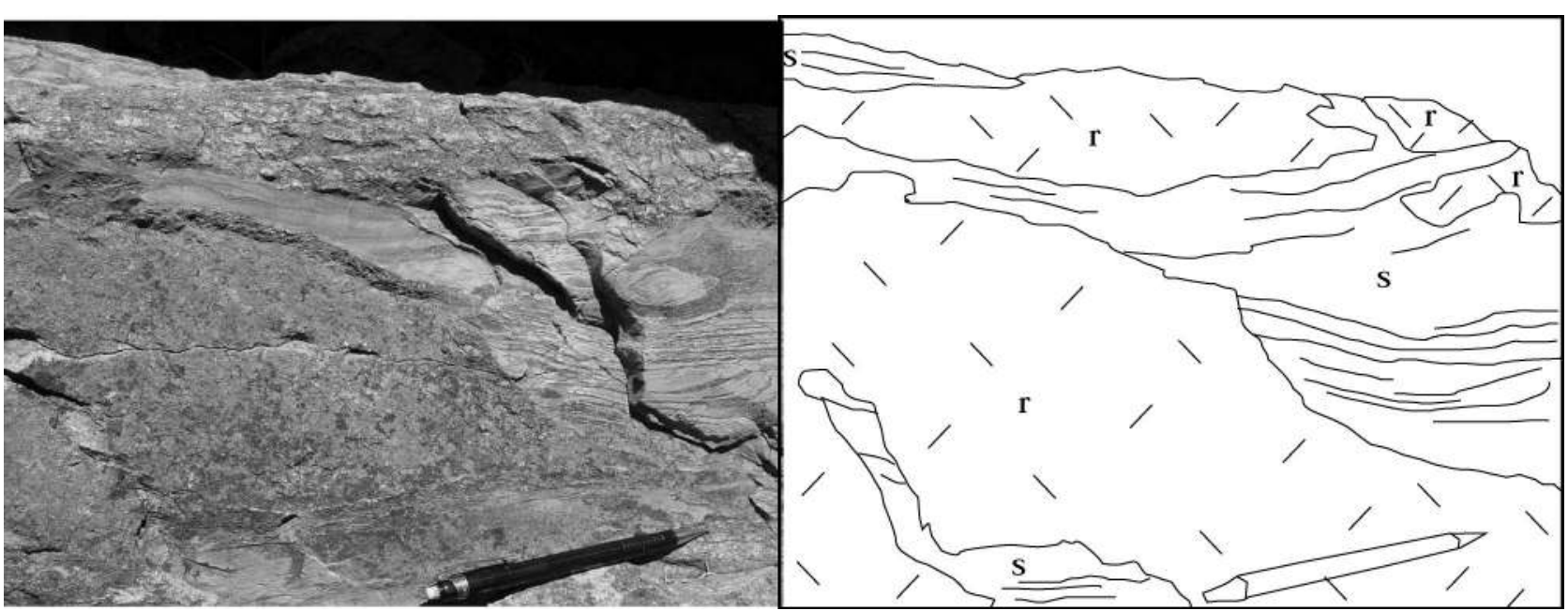

Figure 9 Siltstone-matrix monomictic breccia facies (424840E 6304886N). Delicately laminated siltstone fills spaces between domains and clasts of 8ra rhyolite. Note the siltstone laminae are continuous to contacts with the rhyolite. Line drawing on the right shows the laminated siltstone domains (s) and clasts of 8ra rhyolite (r).

\section{RHYOLITE-DACITE-SILTSTONE BRECCIA}

The rhyolite-dacite-siltstone breccia facies is exposed in the northeastern portion of the study area on the top of three hills: Browns Hill (427726E $6310472 \mathrm{~N})$, south of Browns Hill (427328E 6309720N); and west of Browns Hill (424809E 6309411N) (Figure 3). The exposed unit ranges from 3 to $30 \mathrm{~m}$ in thickness, and is extremely to moderately silica- and chlorite-altered. The breccia is generally clast-supported and has a chaotic and variable texture. Clasts are blocky to cuspate and wispy, elongate, $6 \mathrm{~cm}$ to $1 \mathrm{~m}$, massive to flow-banded rhyolite and dacite (Figure 10a). The matrix is $<5-80$ modal $\%$ of the facies. It consists of quartz and plagioclase crystals $(0.5-3 \mathrm{~mm})$, relic pumice and bubble-wall shards $(0.2-1 \mathrm{~mm})$, and massive to laminated, pale to medium grey, siliceous siltstone that consists of interlocking very fine-grained $(<0.1 \mathrm{~mm})$ quartz and feldspar (Figure 10b). Any original textures in the massive domains may have been destroyed by silicification. The laminated domains are most common at the base and at the top of the breccia.

\section{FIAMME-SILTSTONE BRECCIA}

The term 'fiamme' is used here for elongate lenses or domains of the same mineralogy, texture and composition, which define a pre-tectonic foliation, and are separated by domains of different mineralogy, texture or composition (Bull 2006). The fiamme-siltstone breccia facies consists of 5-25 modal\%, centimetre- to metre-long fiamme within diffusely stratified volcanic siltstone to fine-grained sandstone. The fiamme in this facies are rhyolitic, with $7-15$ modal $\%$ feldspar \pm quartz phenocrysts, and a groundmass of chlorite and very fine-grained quartz and feldspar. The fiamme have an aspect ratio of 10:1 to $3: 1$, are elongated parallel to the diffuse bedding in the siltstone, and their margins are fluidal and ragged to wispy (Figure 11a). The siltstonesandstone is diffusely stratified and normally graded. It consists of plagioclase and quartz grains, and locally contains bubble-wall shards and pumice fragments
(Figure 11b). The exposed thickness of the unit is up to $80 \mathrm{~m}$.

\section{PUMICE-RICH BRECCIA FACIES}

There are three pumice-rich breccia facies (Figure 12), each containing cuspate, blocky or wispy, locally perlitic, chlorite-altered, non-vesicular rhyolite clasts, chlorite-altered rhyolitic pumice clasts, quartz and feldspar crystals, and locally bubble-wall shards. However, the facies vary in grainsize. The coarsest facies, coarse speckled breccia, contains $3-25$ modal $\%$ rhyolite and rhyolitic pumice clasts, $6-50 \mathrm{~cm}$ across, in a massive to diffusely stratified matrix of millimetre-sized crystals, pumice and shards. In some cases, the matrix is finer grained and consists of a mosaic of fine $(\leq 0.1 \mathrm{~mm})$ quartz and K-feldspar ( \pm plagioclase). The coarse speckled breccia commonly, but not in all cases, grades into the speckled breccia facies. The speckled breccia contains granules to pebbles $(2-6 \mathrm{~mm}$, up to $50 \mathrm{~mm}$ ) of rhyolite, in a massive, millimetre-sized matrix of quartz and plagioclase ( \pm K-feldspar) crystals, pumice and shards. The speckled appearance of these two facies arises from the contrast between dark, chlorite-altered rhyolite and pumice clasts, and the pale, quartz- and feldspar-rich matrix.

The finest facies, pumice-crystal-shard sandstone, is diffusely laminated to well-bedded and composed of millimetre-sized quartz and plagioclase crystals, bubblewall shards and pumice fragments in a fine-grained $(\leq 0.1 \mathrm{~mm})$ mosaic of quartz and K-feldspar \pm plagioclase. This facies consists of multiple, 1-4 (up to 20) cmthick beds that are commonly normally graded.

The speckled breccia is the most voluminous facies of the three pumice-rich breccia facies $\left(\sim 3 \mathrm{~km}^{3}\right)$. It commonly grades into the finer grained facies, although beds of the pumice-crystal-shard sandstone facies may locally have sharp contacts with the speckled breccia (Figure 12d). The coarse speckled breccia facies typically has gradational contacts with both of the finer facies, although sharp contacts do occur. 


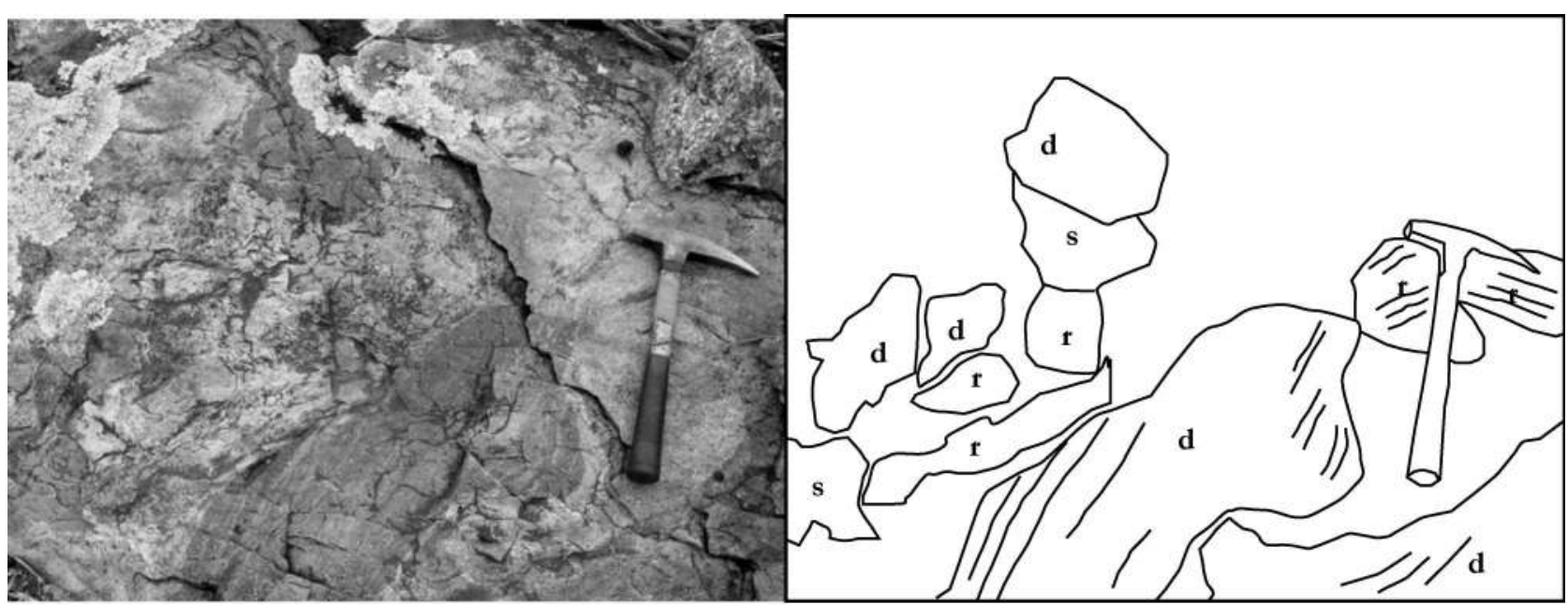

a.

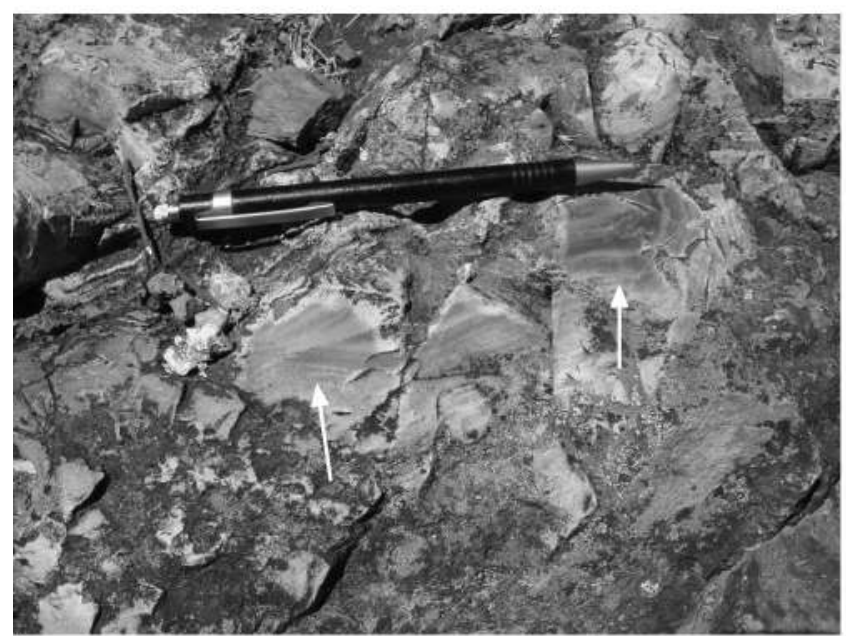

b.

Figure 10 Rhyolite-dacite-siltstone breccia facies. (a) The breccia consists of blocky and elongate clasts of massive to flowbanded quartz-plagioclase-phyric rhyolite (r) and plagioclase-phyric dacite (d), and domains of siltstone (s) (427726E $6310472 \mathrm{~N})$. Outlines of well-defined clasts are shown on the line drawing to the right. (b) The siliceous siltstone domains in the breccia are locally laminated (arrows) $(427646 \mathrm{E} 6310545 \mathrm{~N})$.

\section{Mixed volcanic-sedimentary facies}

The mixed volcanic-sedimentary facies is composed of very thick beds of fine sandstone to pebble conglomerate consisting of a mixture of angular to rounded, volcanic and non-volcanic components. The volcanic components are white, aphyric to porphyritic felsic(?) volcanic fragments, relic pumice, and feldspar and quartz crystals. The non-volcanic components are predominantly siliceous siltstone and, locally, limestone. Beds of normally graded, clast-supported, moderately sorted granule conglomerate to sandstone at the southern end of the Ural Range (425824E 6301921N: Figure 3) contain limestone clasts that include transported marine fossils which yielded a shelly fauna of possible Lochkovian, but more likely Pragian to Emsian age (abundant corals and crinoids, as well as the stromataporoid Atelodictyon: Colquhoun et al. 2005). The beds are $\sim 2-10 \mathrm{~m}$ thick. Locally, interstitial carbonate and pyrrhotite, as well as trace amounts of fluorite grains, also occur in these beds.

\section{Non-volcanic sedimentary facies}

The non-volcanic sedimentary facies include black mudstone, micaceous quartz sandstone and foliated mudstone. The black mudstone facies consists of black to dark grey, 5-10 cm-thick, massive to delicately laminated beds and locally contains bedding-parallel jasper lenses. Traces of pyrite or pyrrhotite may be present. Units of black mudstone facies on Browns Hill overlie the siltstone-matrix monomictic breccia facies (427566E $6310486 \mathrm{~N})$. Other outcrops of black mudstone occur in the northwestern part of the study area $(424884 \mathrm{E} 6309660 \mathrm{~N})$, in the east-central part $(427732 \mathrm{E}$ $6306569 \mathrm{~N})$ and in the south-central part $(427313 \mathrm{E}$ $6304634 \mathrm{~N}$ ) (Figure 3).

The micaceous quartz sandstone facies is commonly interbedded with the foliated mudstone facies. The sandstone consists of subrounded quartz and feldspar $(\sim 70 \%, 0.5 \mathrm{~mm})$, black mudstone $(5-10 \%)$ and muscovite $(5-25 \%, \leq 1 \mathrm{~mm})$ grains in a very fine-grained hematitic matrix. The sandstone is pinkish-grey, 


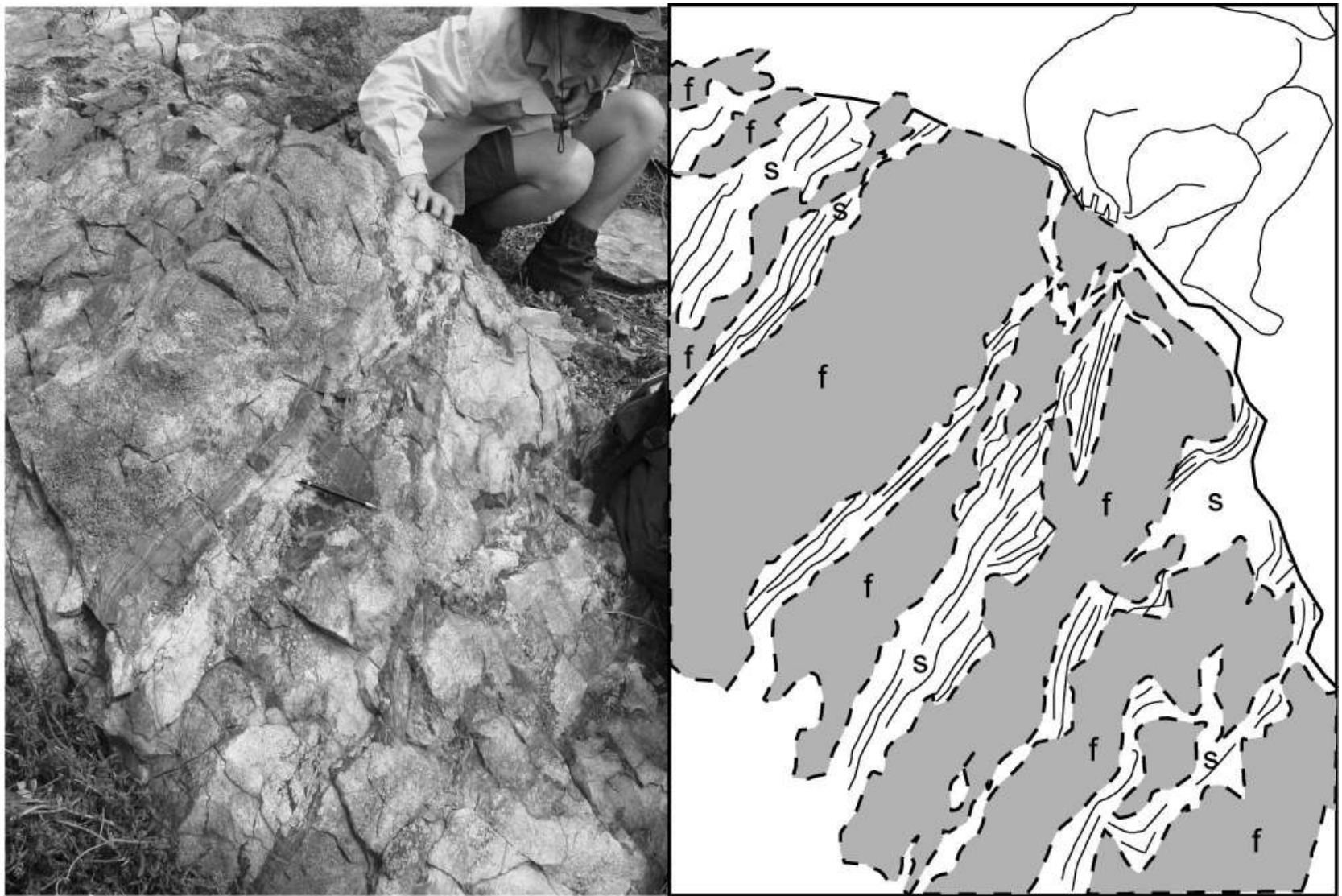

a.

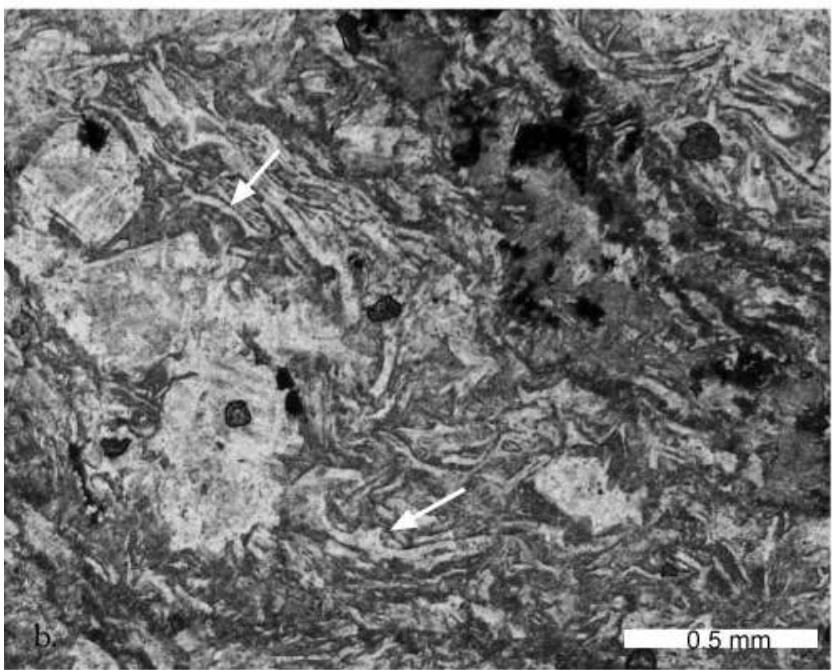

b.

Figure 11 Fiamme-siltstone breccia facies. (a) In outcrop, the fiamme-siltstone breccia facies consists of $\sim 1 \mathrm{~m}$-long fiamme (f) in parallel laminated siltstone (s) (426336E 6307692N). (b) Photomicrograph of the siltstone matrix of the fiamme-siltstone breccia facies (427824E 6308904N). Note the well-preserved bubble-wall shards (arrows). Plane-polarised light.

olive-green or ochre in colour, depending on the degree of surface weathering and oxidation. The interbedded foliated mudstone facies is white, tan or grey.

The interbedded micaceous quartz sandstone and foliated mudstone facies are exposed in the northern Ural Range (425541E 6310114N; 424884E 6309660N; $427100 \mathrm{E} 6310506 \mathrm{~N})$, in the southeastern Ural Volcanics
(432629E 6296930N; 432219E 6295241N), at Mt Whoey $(428819 \mathrm{E} 6331130 \mathrm{~N})$ and at Shepherds Hill Quarry $(429713 \mathrm{E} 6342984 \mathrm{~N})$. Outcrops of these facies are typically in low-lying areas surrounding the more resistant volcanic outcrops, and they consistently underlie the volcanic units. In the southeastern Ural Volcanics, the interbedded micaceous quartz sandstone and foliated 

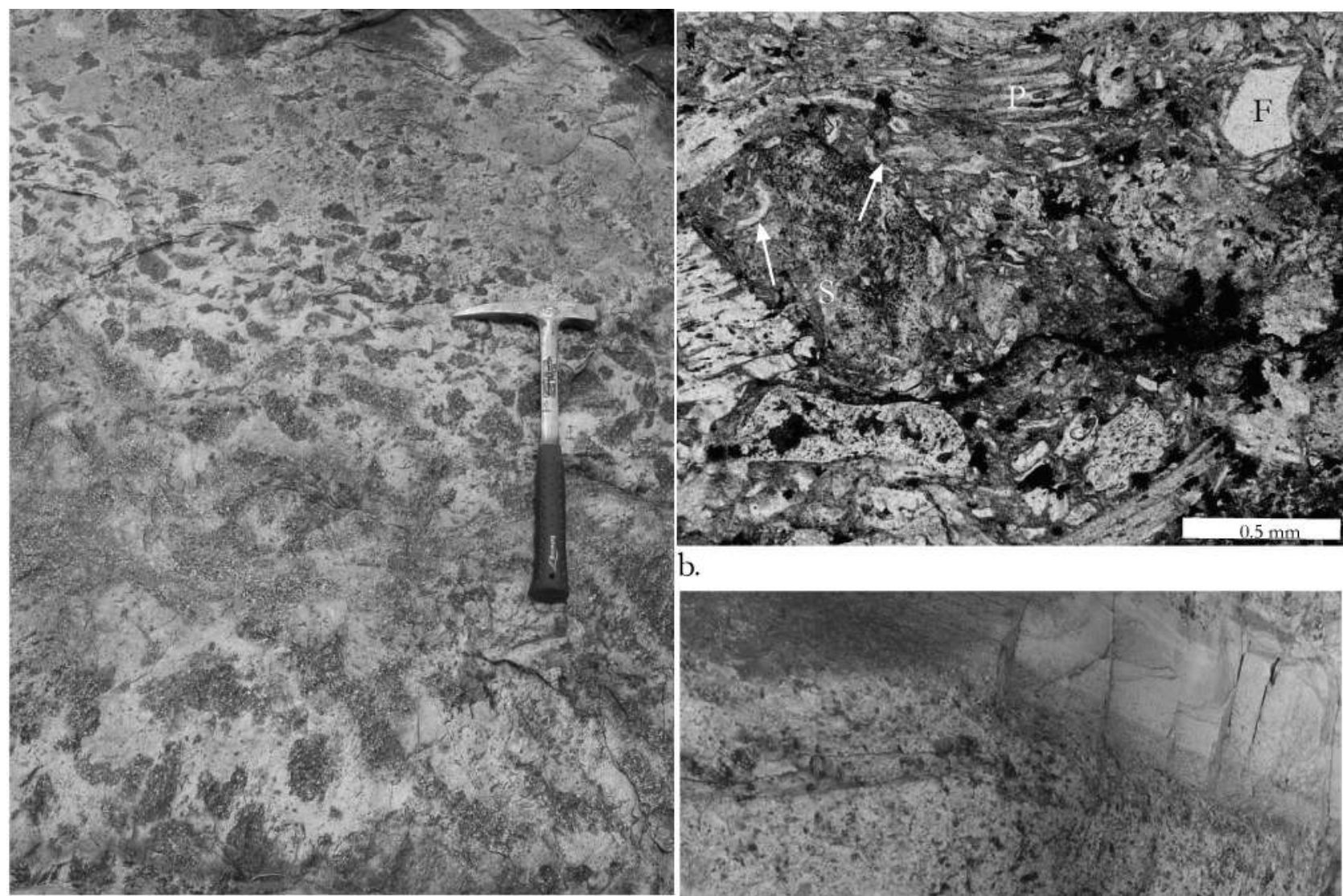

b.

a.
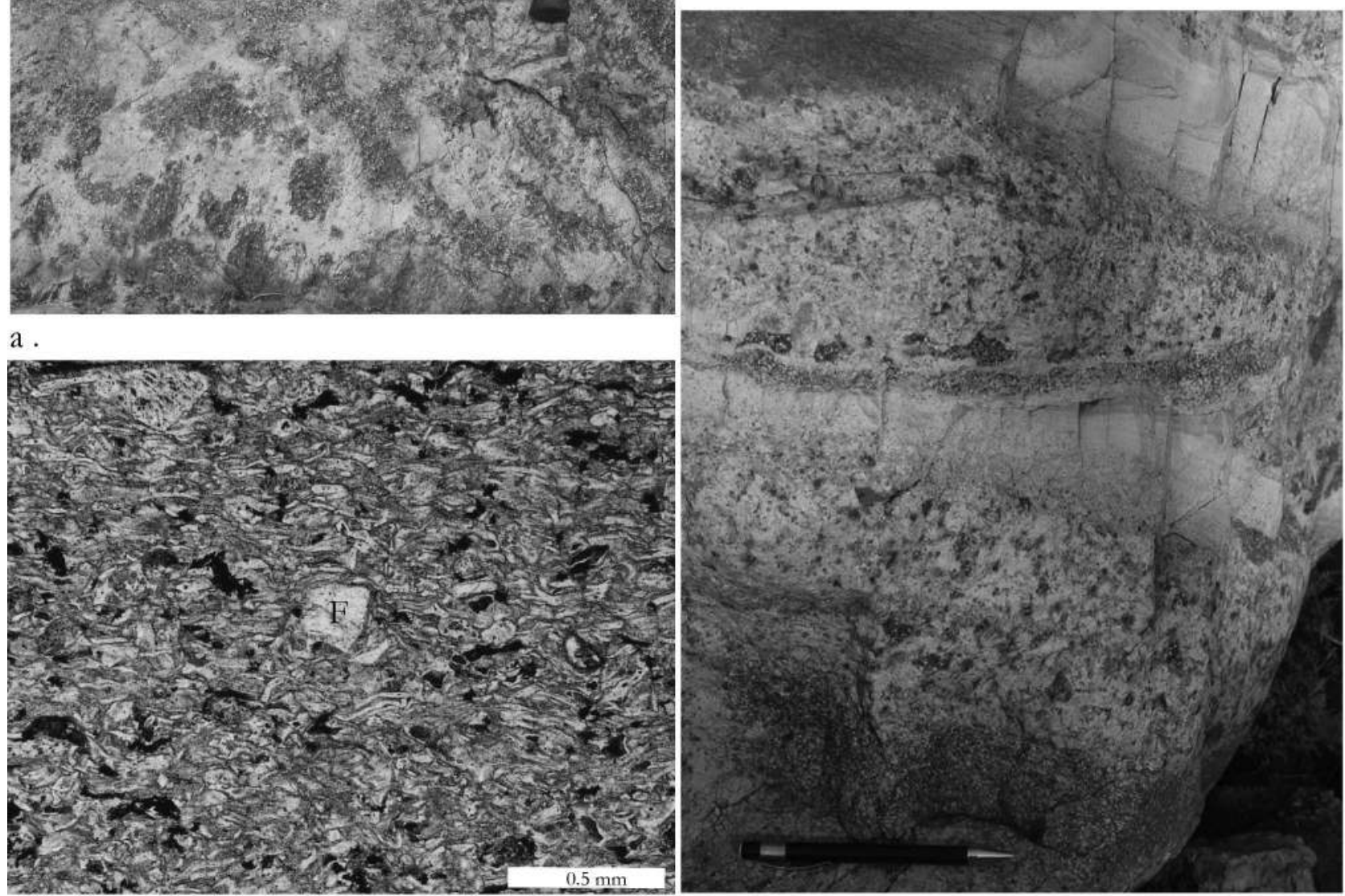

C.

d.

Figure 12 Pumice-rich breccia facies association. (a) Coarse speckled breccia facies showing cuspate to angular, chloritic, porphyritic rhyolite clasts at base, grading to speckled breccia at top (422540E 6304314N). (b) Photomicrograph of speckled breccia facies. Note tube pumice (P), feldspar crystal (F) and bubble-wall shards (arrows) (426336E 6303168N). Plane-polarised light. (c) Photomicrograph of pumice-crystal-shard sandstone to siltstone facies, showing feldspar crystal (F) in shard-rich matrix. Shards are mainly elongate rod-shaped and/or platy and show strong alignment parallel to bedding, and some are chloritically altered (426336E 6303168N). Field of view $2.2 \mathrm{~mm}$; plane-polarised light. (d) Interbedded speckled breccia and pumice-crystal-shard sandstone facies (424209E 6303869N). Note both gradational and sharp contacts. The dark patches are cuspate to blocky, porphyritic rhyolite clasts.

mudstone facies are exposed in topographically higher outcrops but still appear to underlie the volcanic facies. At one location in the northwestern Ural Range $(425541 \mathrm{E}$ $6310114 \mathrm{~N})$, rhyolite unit 6ra interfingers with tan mudstone over several metres (Figure 13). Both units are strongly foliated and sericite-altered. The limited exposure prevents further understanding of the nature of the contact. The consistent stratigraphic position of 
the non-volcanic sedimentary facies underlying the volcanic facies of the Ural Volcanics suggests that the non-volcanic sedimentary facies may correlate with the upper Crossleys Tank or Preston Formations.

\section{Strongly foliated facies}

The strongly foliated facies is a sericite-rich schist with quartz $(\leq 3 \%, 1 \mathrm{~mm})$ and feldspar $(\leq 5 \%, 1 \mathrm{~mm})$ phenocrysts, and centimetre- to metre-thick ochre to white beds. Some beds contain $\sim 1 \%$ white, angular fragments or clasts $(3-7 \mathrm{~mm})$. The schist is exposed in the western Ural Range area (420467E 6305597N) in a 300-m-wide band trending $010^{\circ}$. The schist is in contact with rhyolite unit $16 \mathrm{r}$ to the east and with the speckled breccia facies to the west.

\section{ENVIRONMENT OF DEPOSITION OF THE URAL VOLCANICS}

The mixed volcanic-sedimentary and non-volcanic sedimentary facies in the Ural Volcanics provide the best constraints on the depositional environment of the succession. Clasts of limestone in the mixed volcanicsedimentary facies contain marine fossils. The beds in this facies are very thick and graded, suggesting deposition from gravity currents, and traction-current bedforms are lacking. Hence, we infer that the depositional setting was submarine and below wave-base.

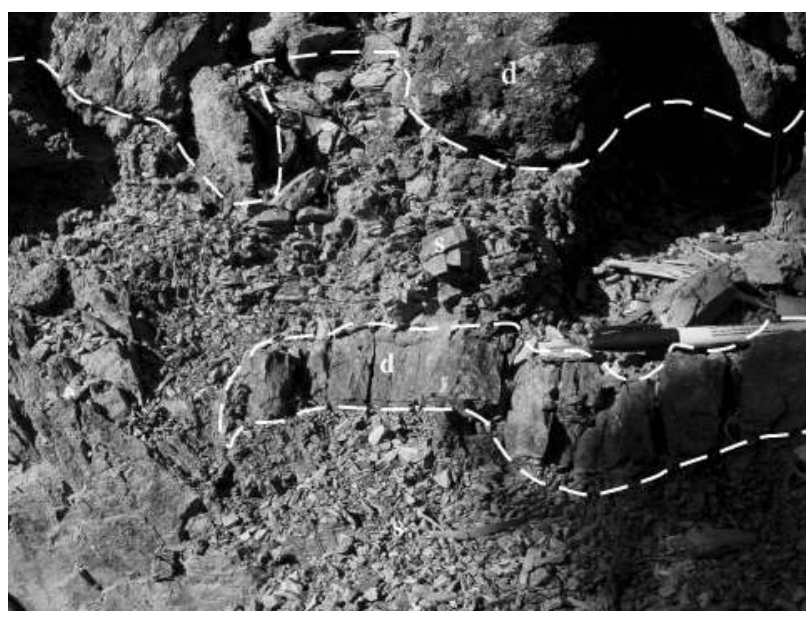

Figure 13 Tongues of $1 \mathrm{~d}$ (d) in tan, foliated siltstone (s), on the northern side of the Ural Range (425541E 6310114N).
The lithofacies characteristics of the non-volcanic sedimentary facies are consistent with a below wavebase depositional setting, which, by association with marine fossil-bearing facies, was submarine. The planar even continuous beds in the black mudstone facies suggest an origin involving pelagic to hemipelagic sedimentation in a below storm wave-base environment. The interbedded micaceous quartz sandstone and foliated mudstone facies are characterised by tabular bed geometry and internal grading, and typical of turbidites deposited below storm wave-base.

Few of the volcanic facies provide any information on the environment of deposition. The exceptions are the coarse speckled breccia and the speckled breccia facies, both of which occur in very thick, massive or diffusely stratified beds, and the pumice-crystal-shard sandstone facies which is planar stratified and commonly well graded. These bed characteristics are consistent with deposition in a subaqueous setting below storm wave-base.

\section{INTERPRETATION OF VOLCANIC FACIES AND FACIES ASSOCIATIONS}

Most of the facies described above can be assigned to two principal volcanic facies associations (Table 3): a felsic coherent facies association and a pumice-rich breccia facies association. The exceptions are the fiamme-siltstone facies and the rhyolite-dacite-siltstone facies, each of which appears to be separate from the associations.

\section{Felsic coherent facies association}

The felsic coherent facies association comprises spatially related, compositionally and texturally similar combinations of felsic coherent facies, monomictic breccia facies and siltstone-matrix monomictic breccia facies. The felsic coherent facies units commonly have the monomictic breccia facies, or the siltstone-matrix monomictic breccia facies, associated with their margins (Figure 3). The clasts in the monomictic breccia facies are identical in composition and phenocryst populations to the adjacent coherent facies. The clasts are angular and cuspate, and commonly flow-banded and rotated. The monomictic breccia facies is interpreted to be autobreccia formed as a result of brittle fragmentation of flowing lava represented by the associated coherent facies.

Table 3 Facies associations in the Ural Volcanics, Ural Range.

\begin{tabular}{ll}
\hline Facies association & Facies (see Table 1) \\
\hline Felsic coherent & Coherent facies, monomictic \\
facies association & breccia facies and siltstone - matrix \\
& monomictic breccia facies
\end{tabular}

Pumice-rich breccia Coarse speckled breccia facies, facies association speckled breccia facies and pumice - crystal - shard volcanic sandstone facies

\section{Association interpretation}

Lavas comprising coherent cores and autobrecciated margins; some lavas have autobreccia carapaces where silt has infiltrated the inter-clast spaces; largely or wholly coherent, high-level intrusions; partly extrusive sills

Syn-eruptive pyroclastic deposits erupted from a local source; beds are coarse-grained close to source, finer grained farther away; deposited from submarine gravity currents and from suspension (finer components) 
EAST SIMONES CLIFF

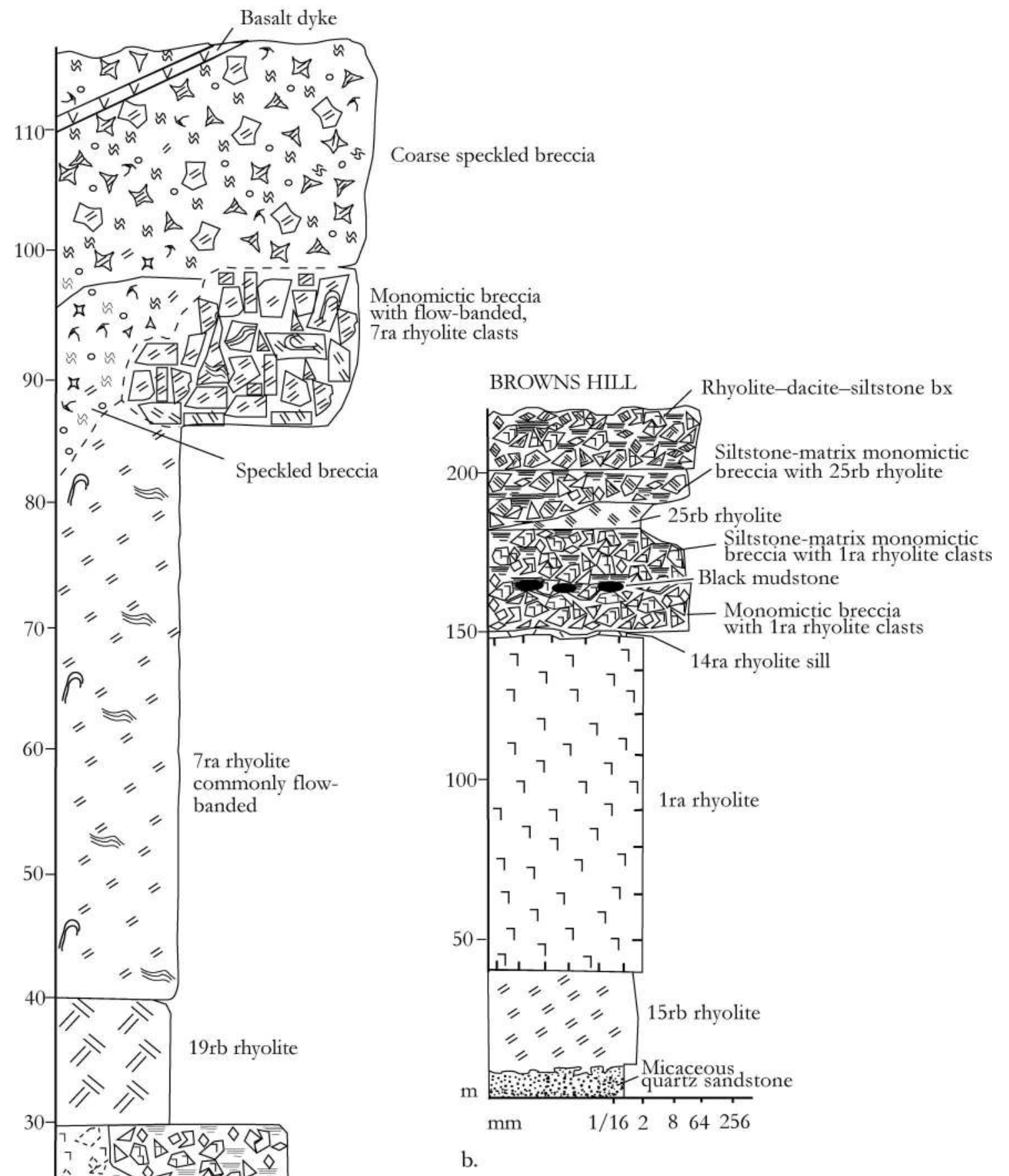

8ra rhyolite

patchy chlorite-sericite

and albite-quartz

domains have created

pseudoclastic texture

$\mathrm{m}$

10

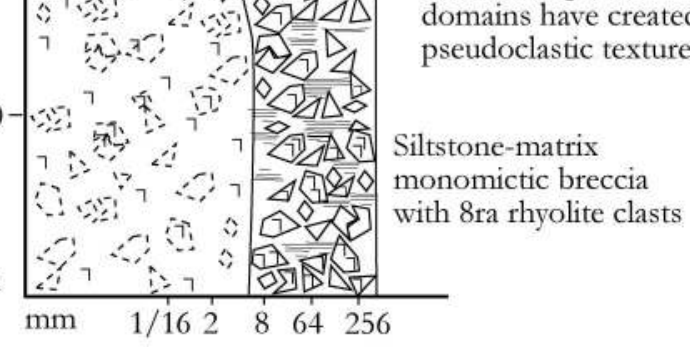

a. 
The siltstone-matrix monomictic facies is very similar to the monomictic breccia facies, but is distinguished by the presence of a laminated siltstone matrix between the clasts. This facies is also interpreted to be autobreccia at the tops and margins of coherent units, but in this case, fine sediment has been deposited in the cracks and crevices between the clasts. The siltstone-matrix monomictic breccia facies is superficially similar to peperite (Skilling et al. 2002). However, the beds in the siltstone matrix are parallel, conformable and continuous to clast margins. The sediment matrix also lacks any sign of induration adjacent to the clasts.

In the Ural Volcanics, many of the coherent facies units have autobreccia and/or siltstone-matrix autobreccia along their top contacts (Figure 3) and are therefore interpreted as lavas. Examples include rhyolite unit 8ra in the south-central region of the map area (Figures 8, 14a), and unit 1 (dacite and rhyolite) in the northeastern map area (Figure 14b). In some cases, the top contacts of coherent units are either not exposed or not associated with autobreccia, so the emplacement mode (extrusive or intrusive) is uncertain.

The areally extensive unit 1 (dacite and rhyolite) is associated with monomictic breccia at several locations, and unit 1 dacite (1d) also appears to completely surround domains of other, apparently unrelated facies (fiamme-siltstone breccia facies) west and northeast of Mt Bowen (426646E 6307798N; 427824E 6308903N). However, near the summit of Mt Bowen, well above the fiamme-siltstone breccia domains (426730E 6307673N), siltstone-matrix monomictic breccia facies composed of unit 1d dacite clasts occurs (Figure 15). The presence of isolated domains of other facies within unit 1d dacite, and its large areal extent, suggest that it is a shallow intrusion, but the local presence of siltstonematrix monomictic breccia suggests that it was extrusive. In this case, the unit may have been a partly extrusive sill.

The rhyolite unit $16 \mathrm{rb}$ is also associated with siltstone-matrix monomictic breccia in the eastern and southern parts of the study area (Figures 3, 16). However, it cuts the stratigraphy on a regional scale from the northeastern map area to the south, as well as on an outcrop scale. This rhyolite unit may also, therefore, have been emplaced as a partly extrusive sill.

\section{Pumice-rich breccia facies association}

The pumice-rich breccia facies association consists of the coarse speckled breccia, the speckled breccia and the pumice-crystal-shard sandstone to siltstone facies. The delicate pumice clasts, bubble-wall shards and angular crystals that dominate this association are probably juvenile pyroclasts, given their igneous origin, fine grainsize and high abundance. By association, the larger, angular to wispy rhyolite clasts are also likely to be pyroclasts. Some of the rhyolite clasts have perlitic groundmasses, indicating that they were originally glassy. Hence, the explosive eruptions that generated this association may have been seated in a fresh, possibly active rhyolitic lava or dome. Notably, the rhyolite clasts in this facies association have a phenocryst assemblage which is very similar to that of rhyolite unit 7ra, and the coarse speckled breccia and speckled breccia lie stratigraphically above rhyolite unit 7ra (Figure 3).

The angular or delicately cuspate shapes of both the coarse and fine components in this facies association imply negligible reworking prior to deposition. The presence of very thick graded or massive beds, and gradational contacts throughout the association, suggests that transport and deposition involved highconcentration particulate gravity currents, especially for the coarser facies, and more-or-less continuous aggradation. The finer facies could also include deposits settled from suspension. Given the uniform composition and juvenile character of the components, transport and deposition were probably syn-eruptive.

The coarse speckled breccia facies is concentrated in a $\sim 300 \mathrm{~m}^{2}$ area in the southwestern central map area (around 423729E 6304528N: Figure 3). In addition, the more extensive speckled breccia facies is thickest in this area, and becomes thinner with distance away from the coarse speckled breccia facies and from the rhyolite unit 7ra . The pumice-rich breccia facies association is thus interpreted to be derived from a source located in the vicinity of the rhyolite unit 7ra.

\section{Rhyolite-dacite-siltstone breccia}

The morphology of the rhyolite and dacite clasts in the rhyolite-dacite-siltstone breccia facies (Figure 10a) suggests that they were derived by fragmentation of lavas, the cuspate margins of some clasts possibly being due to quench fragmentation in a submarine environment. The presence of both rhyolite and dacite clasts, the variations in orientation of the flow bands within the clasts and the variable clast-to-matrix ratio suggest transport of the clasts after fragmentation, perhaps involving downslope resedimentation from adjacent, compositionally different lavas or domes. The bedded siltstone domains are more difficult to interpret. The laminae in these domains are mainly subparallel to local bedding and could have formed as sediment infiltrated the pore spaces between the rhyolite and

Figure 14 Graphic logs showing the felsic coherent and monomictic breccia facies association. (a) East Simones Cliff area (see Figure 3 for location). The base of the log shows siltstone-matrix monomictic breccia facies containing clasts of 8ra rhyolite, overlying and adjacent to 8ra rhyolite, indicating that 8ra rhyolite is extrusive. In addition, 7ra rhyolite is associated with an overlying monomictic breccia facies containing clasts of 7ra rhyolite. The upper part of the log shows the relationship between the coarse speckled breccia and the speckled breccia facies, both of which overlie 7ra rhyolite and its associated monomictic breccia. (b) Browns Hill (see Figure 3 for location). Monomictic breccia and siltstone-matrix monomictic breccia overlie 1ra rhyolite, and both contain clasts of 1ra rhyolite. Siltstone-matrix monomictic breccia overlies $25 \mathrm{rb}$ rhyolite and contains clasts of $25 \mathrm{rb}$ rhyolite. The rhyolite-dacite-siltstone breccia facies occurs at the top of the section and is not associated with any coherent facies. Note the vertical scale differs in the two logs. 


\section{WEST MOUNT BOWEN}

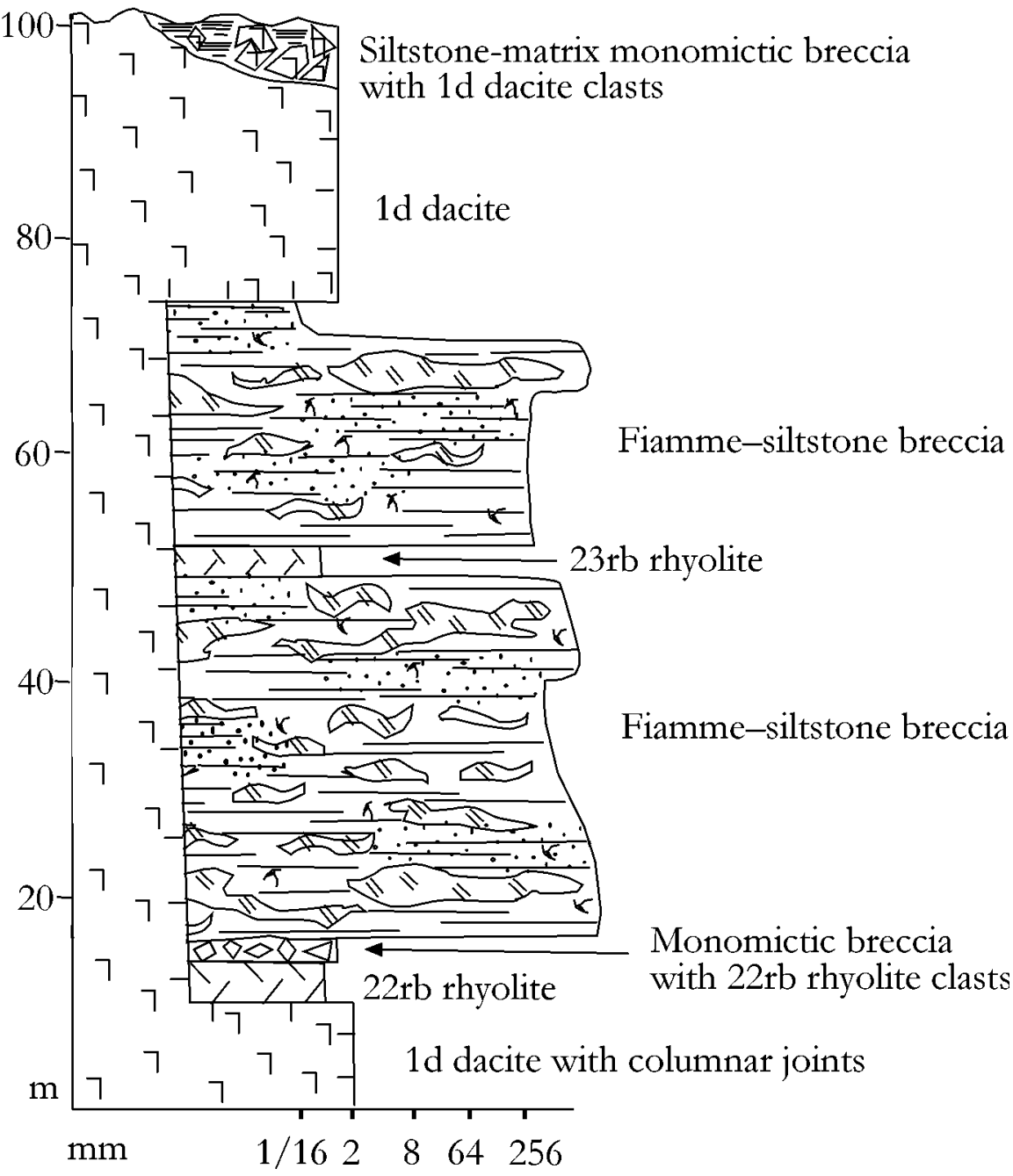

Figure 15 Graphic log of west Mt Bowen. 1d dacite encloses screens of fiamme-siltstone breccia facies and 22 rb rhyolite and $23 \mathrm{rb}$ rhyolite lavas, whereas the top of $1 \mathrm{~d}$ dacite is associated with a siltstone-matrix monomictic breccia, suggesting that $1 \mathrm{~d}$ dacite is a partly extrusive sill. dacite clasts. However, sediment domains are strongly silica- and chlorite-altered, and the possibility that they are intraclasts cannot be discounted. The presence of this facies implies the existence of a topographically higher source of rhyolite and dacite clasts that is no longer preserved.

\section{Fiamme-siltstone breccia}

The porphyritic texture of the fiamme in the fiammesiltstone breccia facies, and the textural contrast with the adjacent siltstone, indicate that they are clasts of igneous origin. The shapes of the fiamme and their alignment parallel to bedding suggest that they have undergone compaction, in turn implying that they were originally porous (that is, pumice). These large (up to $1 \mathrm{~m}$ long), now-compacted pumice clasts were deposited at the same time as much of the finer matrix. The strongly bimodal grainsize, and the laminated character of the fine matrix in this facies, can only be accounted for by settling of both the coarse and fine components from suspension. Most rhyolitic pumice clasts are less dense than water, and will be at least temporarily buoyant, especially coarse pumice clasts (Whitham \&
Sparks 1986; Cashman \& Fiske 1991; Manville et al. 1998). They may be deposited at the same time as much finer sediment suspended in the water column. In this case, the sediment was probably pyroclastic ash, given that it consists of bubble-wall shards, pumice and angular crystal fragments. The coarse pumice clasts could also be pyroclasts or, alternatively, spalled from the pumiceous carapace of a lava or dome (Clough et al. 1981).

\section{FACIES ARCHITECTURE OF THE URAL VOLCANICS}

The facies architecture of the Ural Range area is typical of subaqueous volcanic successions that are dominated by felsic lavas and sills (Figure 17) (Allen et al. 1996b; Paulick \& McPhie 1999; Doyle \& McPhie 2000). An important feature of the lavas is the substantial volume of autoclastic facies present and the predominance of autobreccia. Although pyroclastic facies are present, they are volumetrically minor.

At least $75 \%$ of the exposed Ural Volcanics belongs to the felsic coherent facies association. Single coherent units have volumes up to $3.5 \mathrm{~km}^{3}$ (e.g. $16 \mathrm{rb}$ : Table 2) and 
SOUTHERN MAP AREA

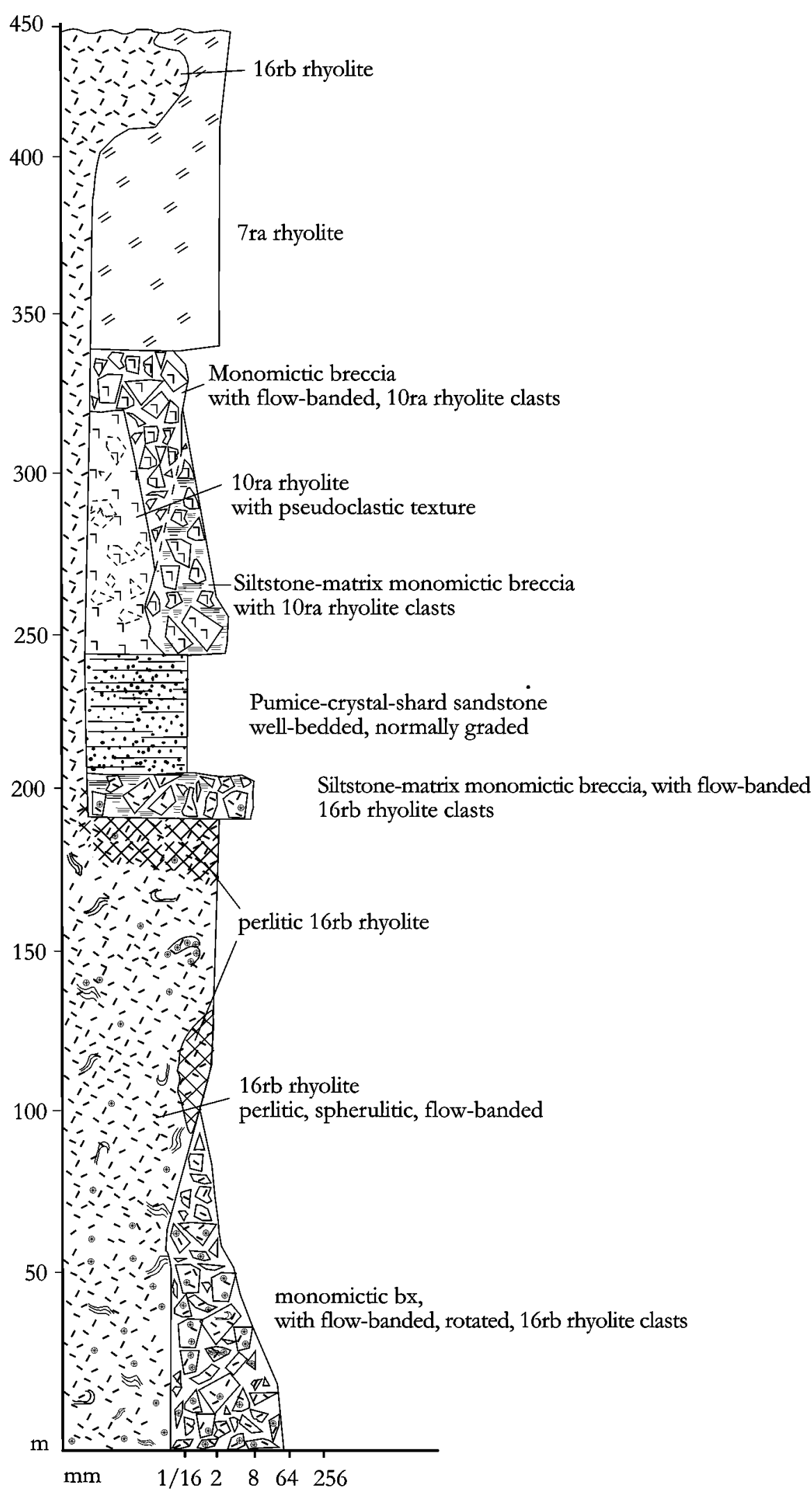

Figure 16 Graphic log from the southern map area (see Figure 3). $16 \mathrm{rb}$ rhyolite is locally associated with monomictic breccia (base of log) but shows intrusive relationships with other units, suggesting that it is a partly extrusive sill. have either sharp, passive margins or are enveloped by intervals of monomictic breccia or siltstone-matrix monomictic breccia. At least 12 of the mapped felsic coherent units in this association are lavas, 12 are intrusions, and 11 could be either (Table 2). All coherent basalt-andesite units have steeply dipping, sharp, cross-cutting contacts with surrounding units and are considered to be dykes. 


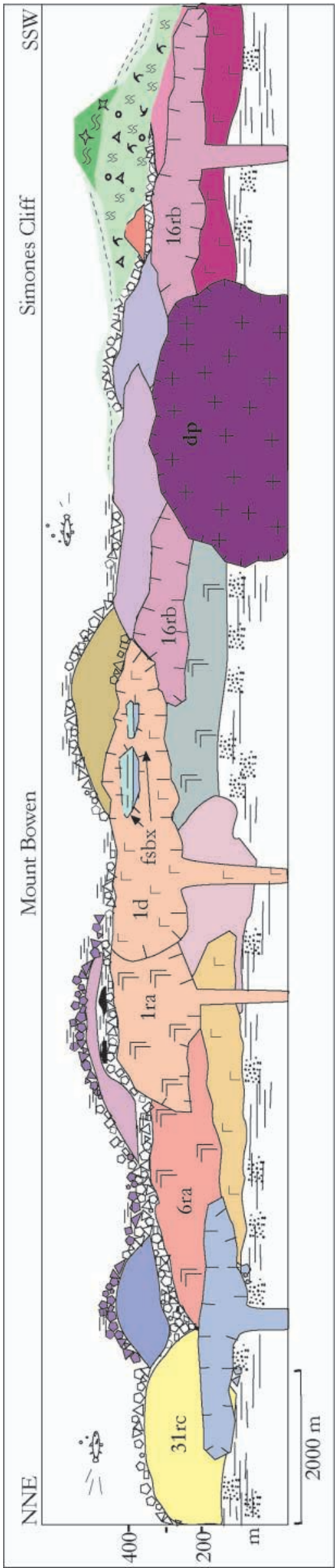

电可

㐘 $\dot{\hat{1}} \cdot \frac{\pi}{0}$

证

के

.

要

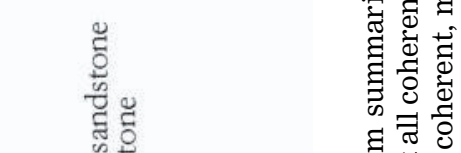

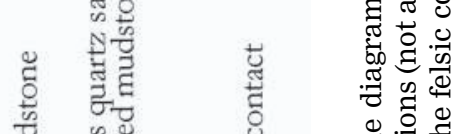

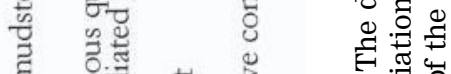

ह

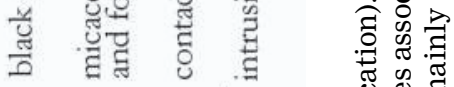

1 湖ᄂ

चु s

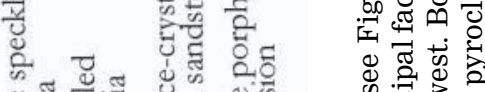

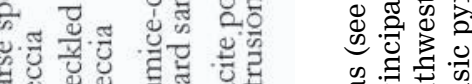

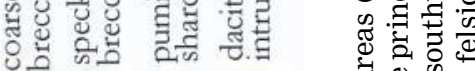

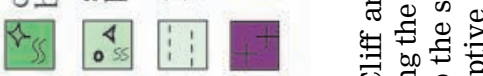

प्ञ

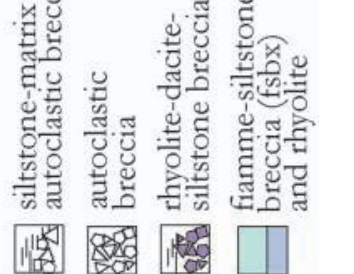

胥范

क्षे क्ते

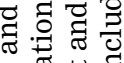

需

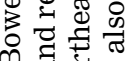

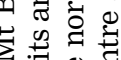

๑ 웡

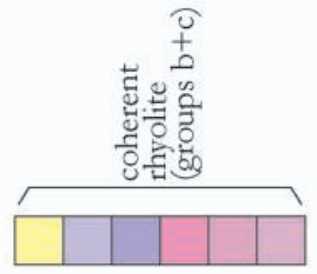

워용

क्ष

ठิ ธิ ثี

赵我

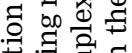

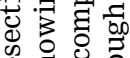

के क्ष

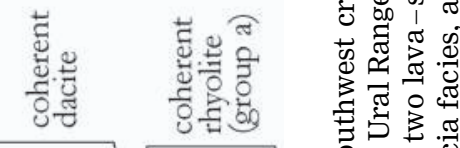

प

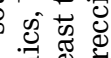

苋芯志

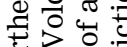

西

눙

䒕豆 范

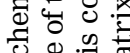

记

=

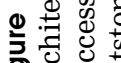


Volcaniclastic facies make up the majority of the remaining $25 \%$ of the map area. The pumice-rich breccia facies association is the most extensive, accounting for $\sim 15-20 \%$ of the Ural Volcanics in the Ural Range. The speckled breccia facies is the largest volume facies $\left(\sim 3 \mathrm{~km}^{3}\right)$ of the association and is exposed over $\sim 20 \mathrm{~km}^{2}$. This facies association conformably overlies felsic lavas and is cut by felsic intrusions. The preserved volume of the fiamme-siltstone breccia facies accounts for only a small percentage of the total Ural Volcanics $(<5 \%)$. However, the original volume may have been substantially larger because all exposed remnants are entirely enclosed by the intrusive part of dacite unit $1 \mathrm{~d}$. The pumice-rich breccia facies association and the fiamme-siltstone breccia facies both have syn-eruptive pyroclastic origins.

The mixed volcanic-sedimentary and non-volcanic sedimentary facies total $<1 \%$ of the Ural Volcanics volume. Intervals of these facies have gradational and interfingering contacts with the coherent and volcaniclastic facies, and are no more than $\sim 50 \mathrm{~m}$ thick. Lateral extents are commonly limited to less than $100 \mathrm{~m}$.

\section{LOCATION AND CHARACTER OF VOLCANIC CENTRES IN THE URAL VOLCANICS}

In the Ural Range, at least two felsic volcanic centres have been recognised. The predominance and distribution of felsic lavas and sills in the northern part of the study area suggest the presence there of at least one multiple-vent effusive volcanic centre. To the south, grainsize variations in syn-eruptive pyroclastic facies (pumice-rich breccia facies association) are consistent with the presence of another eruptive centre that was both effusive and explosive. The speckled breccia facies overlies $\sim 100 \mathrm{~m}$ of lavas and sills, and thins laterally from $\sim 100 \mathrm{~m}$ thick, where it underlies the coarse speckled breccia facies, to $\sim 10 \mathrm{~m}$ thick, as much as $9 \mathrm{~km}$ away. In addition, the coarse speckled breccia and the speckled breccia facies both grade into the pumicecrystal-shard sandstone facies, and all facies contain rhyolite clasts that can be matched with 7ra rhyolite, suggesting that the vent may have been seated within the 7ra rhyolite lava. The source eruptive centre for these facies is therefore interpreted to have been in the southern part of the Ural Range, east of Simones Cliff, and produced both effusive and explosive eruptions.

The source of the fiamme-siltstone breccia facies is less certain. This facies is also a syn-eruptive pyroclastic facies, but is exposed as screens within a sill, and the original underlying and overlying stratigraphy is missing. Although the fiamme are very large, their size is of little significance with regard to distance from source because coarse pumice clasts may remain buoyant long enough to be transported far from their source (Simkin \& Fiske 1983). Nevertheless, given that there was a local supply of coarse pumice, either spalled from pumiceous carapaces of lavas or erupted explosively, a nearby source is entirely plausible.

\section{PROSPECTIVITY OF THE URAL VOLCANICS IN THE URAL RANGE}

The prospectivity of the Ural Volcanics can be considered with respect to two potential ore deposit styles: volcanic-hosted massive sulfide (VHMS) mineralisation associated with Early Devonian submarine volcanic activity, and epigenetic vein mineralisation associated with Middle Devonian to Early Carboniferous faults.

The setting, felsic composition and association of coherent, autoclastic and syn-eruptive pyroclastic facies in the Ural Volcanics are typical of submarine volcanic successions that host important massive sulfide ore deposits [e.g. Bergslagen, Sweden (Allen et al. 1996a); Mt Read Volcanics, Tasmania (McPhie \& Allen 1992); Iberian Pyrite Belt, Portugal and Spain (Mitjavila et al. 1997)]. VHMS ore deposits are thought to be deposited on the seafloor or as sub-seafloor replacement, more or less synchronous with volcanic activity and sedimentation (Binns \& Scott 1993; Allen et al. 1996a, b; Large et al. 2001). Seafloor and sub-seafloor stratigraphic positions are therefore common targets in exploration for VHMS deposits.

At least two seafloor positions in the Ural Volcanics are marked by black mudstone containing jasper lenses: one is exposed above siltstone-matrix monomictic breccia on Browns Hill (427726E 6310472N), and the second overlies fiamme-siltstone breccia facies northeast of Mt Bowen (427210E 6308146N). The sedimentary beds in these areas are only centimetres to possibly a metre thick, and no sulfides have been identified. The Ural Volcanics in the Ural Range are also lacking in the intensely chlorite-chalcopyrite- or silica-sericitepyrite-altered domains typically found below and/or around VHMS ore deposits (Large et al. 2001). However, volcanic and sedimentary facies, and coherent facies compositions in the volcanic rocks of the Iberian Pyrite Belt are very similar to those in the Ural Volcanics (Rosa et al. 2004a, b, c), suggesting that the prospectivity of the Ural Volcanics for seafloor massive sulfide deposits should be high.

Regionally, epigenetic, vein-style ore deposits and altered domains are associated with steeply dipping, Devonian to Carboniferous faults, although exploration along these structures in the Ural Range has yielded little in terms of metal abundances (Stanley 1982; Rayner 1984). Surface exposures of such poorly resistant zones are limited, however, and the potential for deeper ore deposits along these structures may be good.

\section{CONCLUSIONS}

The Ural Volcanics form topographic highs on a northsouth trend for over $100 \mathrm{~km}$ of present-day outcrop, and are mainly composed of Lower Devonian, submarine, rhyolitic to dacitic lavas and sills erupted from intrabasinal vents. In the Ural Range, the Ural Volcanics are exceptionally well exposed, providing a rare opportunity to reconstruct the facies architecture and identify volcanic vents. Detailed 1:10000 scale mapping in the Ural Range defined at least 50 map units that include 35 separate felsic lavas and sills, two syn-eruptive felsic 
pyroclastic units, several felsic and mafic dykes, and small mafic intrusions. Mixed provenance and nonvolcanic sedimentary facies are minor and interbedded with the volcanic facies. Shallow to moderate dips to the southeast to southwest, and upward younging, indicate that the major structure is a southwest-plunging, upright, open anticline.

Rhyolitic and dacitic lavas and sills that dominate the northern Ural Range delineate at least one, local, effusive eruptive centre. Syn-eruptive pyroclastic units occur in the southwest-central Ural Range. Grainsize and thickness variations in one unit suggest that it was erupted from a nearby, intrabasinal, explosive vent. The other syn-eruptive pyroclastic unit consists of watersettled ash and coarse pumice clasts (now fiamme) and could also be the product of the same, or another, local explosive eruption.

\section{ACKNOWLEDGEMENTS}

This study is part of $\mathrm{PhD}$ research by KFB at the Centre for Ore Deposits Research (CODES-SRC) and School of Earth Sciences, University of Tasmania. Funding and in-kind support were provided by CODES-SRC, the Geological Survey of New South Wales, and a Society of Economic Geologists Hugh McKinstry grant. Carol Simpson and Simone Meakin are due great thanks for suggesting and encouraging the study of the Ural Volcanics. Simone Meakin, Gary Colquhoun and Roger Cameron are also thanked for their generous support in the field and in the office. Careful and constructive reviews by Richard Facer, Gary Colquhoun, Elizabeth Jagodzinski and Kelsie Dadd were extremely helpful. Sincere thanks are also extended to the property owners around the Ural Range and residents of Lake Cargelligo who allowed access, maintained radio contact and offered substantial logistical support.

\section{REFERENCES}

Allen R. L., Lundstrom I., RiPA M., Simeonov A. \& CHRISTOFFERSON H. 1996a. Facies analysis of a $1.9 \mathrm{Ga}$, continental margin, backarc, felsic caldera province with diverse $\mathrm{Zn}-\mathrm{Pb}-\mathrm{Ag}-(\mathrm{Cu}-\mathrm{Au})$ sulfide and $\mathrm{Fe}$ oxide deposits, Bergslagen region, Sweden. Economic Geology 91, 979-1008.

Allen R. L., Weined P. \& Svenson S. A. 1996b. Setting of Zn-Cu$\mathrm{Au}-\mathrm{Ag}$ massive sulfide deposits in the evolution and facies architecture of a $1.9 \mathrm{Ga}$ marine volcanic arc, Skellefte District, Sweden. Economic Geology 91, 1022-1053.

BINNS R. A. \& ScoTT S. D. 1993. Actively forming polymetallic sulfide deposits associated with felsic volcanic rocks in the eastern Manus back-arc basin, Papua New Guinea. Economic Geology 88, $2226-2236$

BLEVIN P. L. 2003. Notes on the chemistry of igneous units in the Cargelligo 1:250 000 sheet area, NSW. Geological Survey of New South Wales Report GS 2003/448 (unpubl.).

Blevin P. L. 2004. Chemistry of igneous units on the Cargelligo 1:250 000 sheet, NSW (updated and revised). Geological Survey of New South Wales File GS2004/451 (unpubl.).

BULL K. F. 2006. Facies architecture, geochemistry and tectonic significance of the Ural Volcanics and the Mount Hope Volcanics, Central Lachlan Fold Belt, NSW. PhD thesis, University of Tasmania, Hobart (unpubl.).
CAS R. A. F. 1983. Palaeogeographic and tectonic development of the Palaeozoic Lachlan Fold Belt of southeastern Australia. Geological Society of Australia, Special Publication 10.

CASHMAN K. V. \& Fiske R. S. 1991. Fallout of pyroclastic debris from submarine volcanic eruptions. Science 253, 275-280.

Clough B., Wright J. \& WAlker G. 1981. An unusual bed of giant pumice in Mexico. Nature 289, 49-50.

Colquhoun G. P., Meakin N. S. \& Cameron R. G. 2005. Cargelligo 1:250000 Geological Sheet SI/55-6 (3rd Edition) Explanatory Notes. Geological Survey of New South Wales, Sydney.

DownES P. M. 2005. Metallic mineral occurrence data. In: Colquhoun G. P., Meakin N. S. \& Cameron R. G. eds. Cargelligo 1:250000 Geological Sheet SI/55-6 (3rd Edition) Explanatory Notes. Appendix 5. Geological Survey of New South Wales, Sydney.

DoYLE M. \& MCPHIE J. 2000. Facies architecture of a felsic intrusiondominated volcanic centre at Highway-Reward, Queensland, Australia. Journal of Volcanology and Geothermal Research 99, $79-96$.

Glen R. A., Clare A. \& Spencer R. 1996. Extrapolating the Cobar Basin model to the regional scale; Devonian basin-formation and inversion in western New South Wales. In: Cook W. G., Ford A. J. H., McDermott J. J., Standish P. N., Stegman C. L. \& Stegman T. M. eds. The Cobar Mineral Field-a 1996 Perspective, pp. 43-88. Australasian Institute of Mining and Metallurgy Spectrum Series 3/96.

Gradstein F. M. \& OGG J. G. 2004. Geologic time scale 2004-why, how and where next? Lethaia 37, 175-181.

GRIFFIN R. J. 1960. The geology and mineral resources of the Euabalong 4-mile military sheet. New South Wales Department of Mines, Technical Report 5, 163-205.

King P., White A., ChApPell B. \& Allen C. 1997. Characterization and origin of aluminous A-type granites from the Lachlan Fold Belt, southeastern Australia. Journal of Petrology 38, $371-391$.

Large R., McPhie J., Gemmell J., Herrmann W. \& Davidson G. 2001. The spectrum of ore deposit types, volcanic environments, alteration halos and related exploration vectors in submarine volcanic successions: some examples from Australia. Economic Geology 96, 913-938.

MANIW J. G. 1980. Lake Cargelligo area, exploration reports. Electrolytic Zinc Co. of Australasia, Ltd., Mineral Resources Division. Geological Survey of New South Wales File GS 1980/ 334 (unpubl.).

MANIW J. G. 1983. Summary report on exploration and results at Browns Reef and the Preston licences, Lake Cargelligo, NSW. Electrolytic Zinc Co. of Australasia Ltd., Mineral Resources Division. In: Rayner H. E. ed. Jennings Industries Limited, Final report on all licences in Preston and Browns Reef group; prospecting licences 591, 592, 593, 594, 596, 597, 605, 606, 607, 634, 635, 901, 902, 903, 619 (Preston) Lake Cargelligo area, N.S.W. Geological Survey of New South Wales File GS1984/288 (unpubl.).

Manville V., White J., Houghton B. \& Wilson C. 1998. The saturation behaviour of pumice and some sedimentological implications. Sedimentary Geology 119, 5-16.

MCPHIE J. \& ALLEN R. L. 1992. Facies architecture of mineralised submarine volcanic sequences: Cambrian Mount Read Volcanics, western Tasmania. Economic Geology 87, 587-598.

MCPhiE J., DoYle M. \& AlLEN R. L. 1993. Volcanic Textures: a Guide to the Interpretation of Textures in Volcanic Rocks. University of Tasmania Centre for Ore Deposit and Exploration Studies, Hobart.

Meakin S., CAmeron R. G., Colquhoun G. P., Simpson C. \& BARRon L. M. 2002. The Ural Volcanics: a Siluro-Devonian felsic volcanic succession in central NSW. Geological Society of Australia Abstracts 67, 244.

MitJAVILA J., MARTI J. \& SoRIANO C. 1997. Magmatic evolution and tectonic setting of the Iberian Pyrite Belt volcanism. Journal of Petrology 38, 727-755.

O'CONNOR D. P. H. \& SANGSTER D. F. 1980. Evidence of an exhalative origin for deposits of the Cobar district, New South Wales. Discussion and Reply. BMR Journal of Australian Geology \& Geophysics 5, 70-73.

PAUlicK H. \& MCPHIE J. 1999. Facies architecture of the felsic lavadominated host sequence to the Thalanga massive sulfide deposit, Lower Ordovician, northern Queensland. Australian Journal of Earth Sciences 46, 391-405. 
PaUlL P. L. 1987. Pan Australian Mining Ltd: Exploration Licences 2346 and 2347; report for the period 8 January 1987 to 7 July 1987; fifth and sixth monthly report, Langtree project. Pan Australian Mining Ltd. Geological Survey of New South Wales File GS 1987/195 (unpubl.).

Pogson D. J. 1967. Cargelligo 1:250000 Geological Sheet SI 55-6 and Explanatory Notes. Geological Survey of New South Wales, Sydney.

RAYNER H. E. 1984. Final report for all licences in Preston and Browns Reef group, prospecting licences 591-594, 596, 597, 605-609, 634, 635, 901-904, 619 (Preston) Lake Cargelligo area, N.S.W. (Jennings Industries Limited). Geological Survey of New South Wales File GS 1984/288 (unpubl.).

RoberTSON I. D. M. \& TAYLOR G. F. 1987. Depletion haloes in fresh rocks surrounding the Cobar ore bodies, N.S.W., Australia: implications for exploration and ore genesis. Journal of Geochemical Exploration 27, 77-101.

Rosa C., McPhiE J. \& ReLVAS J. 2004a. Volcanic setting of massive sulfide deposits in the Iberian Pyrite Belt, Portugal. Geological Society of Australia Abstracts 73, 288.

Rosa C., McPhie J., Relvas J., Pacheco N. \& Ferreira A. 2004b. Intrabasinal submarine volcanoes at Neves-Corvo in the Iberian Pyrite Belt, Portugal. IAVCEI General Assembly 2004, Pucon, Chile. Abstract.

Rosa D., Inverno C., Oliveira V. \& Rosa C. 2004c. Geochemistry of volcanic rocks, Albernoa area, Iberian Pyrite Belt, Portugal. International Geology Review 46, 366-383.

ScheIBNER E. 1998. Silurian-Middle Devonian. In: Scheibner E. \& Basden H. eds. Geology of New South Wales-Synthesis Volume 2, pp. 141-189. Geological Survey of New South Wales Memoirs Geology 13(2).
SCHEIBNER E. \& BARRON L. 1985. The Mount Hope Group and comagmatic granites in the Mount Hope area, New South Wales, pp. 141-163. In: Sutherland F. L., Franklin B. J. \& Waltho A. E. eds. Volcanism in Eastern Australia, with Case Histories from New South Wales, vol. 2, pp. 141-163. Geological Society of Australia, New South Wales Division, Sydney.

SIMKIN T. \& FISKE R. 1983. Krakatau 1883: the Volcanic Eruption and its Effects. Smithsonian Institute Press, Washington.

SKILling I., White J. \& McPhiE J. 2002. Peperite: a review of magma-sediment mingling. Journal of Volcanology and Geothermal Research 114, 1-17.

STANLEY G. D. 1982. Third six-monthly exploration progress report and final report, period 9/3/82 to 8/9/82 (Shell Company of Australia Ltd.). Geological Survey of New South Wales File GS 1982/454 (unpubl.).

STEGMAN C. 2001. Cobar deposits: still defying classification! Society of Economic Geologists Newsletter 44, 15-26.

SuPPEL D. W. \& SCHEIBNER E. 1990. Lachlan Fold Belt in New South Wales-regional geology and mineral deposits. In: Hughes F. E. ed. Geology of the Mineral Deposits of Australia and Papua New Guinea, pp. 1321-1327. Australasian Institute of Mining and Metallurgy Monograph 14.

TRIGG S. J. 1987. Geology of the Kilparney 1:100000 Sheet 8132. Geological Survey of New South Wales, Sydney.

Whitham A. \& SpARKS R. 1986. Pumice. Bulletin of Volcanology 48 , $209-223$.

Received 9 March 2005; accepted 8 March 2006 